$$
\begin{array}{ccccccc}
\text { L } & \text { E } & \text { T } & \text { u } & \text { v } & \text { O } & \text { s } \\
\hline \text { ARCHEOlogija } & 46
\end{array}
$$


Lietuvos istorijos institutas

\begin{tabular}{llllllll}
$\mathrm{L}$ & $\mathrm{I}$ & $\mathrm{E}$ & $\mathrm{T}$ & $\mathrm{U}$ & $\mathrm{V}$ & $\mathrm{O}$ & $\mathrm{S}$ \\
\hline
\end{tabular}

ARCHEOlogija 46 


\section{Leidybą finansavo}

\section{LIETUVOS MOKSLO TARYBA}

PAGAL VALSTYBINĘ LITUANISTINIŲ TYRIMŲ IR SKLAIDOS 2016-2024 METŲ PROGRAMĄ

(Finansavimo sutarties numeris S-LIP-19-4)

\section{Redaktorių kolegija / Editorial board:}

Atsakingoji redaktorė / Editor-in-chief dr. Agnè Čivilytė (Lietuvos istorijos institutas, Vilnius / Lithuanian Institute of History, Vilnius)

Atsakingosios redaktorès pavaduotoja / Assistant Editor dr. Elena Pranckènaitè (Lietuvos istorijos institutas, Vilnius / Lithuanian Institute of History, Vilnius)

Dr. Laurynas Kurila (Lietuvos istorijos institutas, Vilnius / Lithuanian Institute of History, Vilnius)

Dr. Valdis Bērziņš (Latvijos universitetas, Latvijos istorijos institutas, Ryga / University of Latvia, Institute of Latvian History, Riga)

Habil. dr. Anna Bitner-Wróblewska (Valstybinis archeologijos muziejus Varšuvoje, Lenkija / State Archaeological Museum in Warsaw, Poland)

Dr. Christoph Jahn (Baltijos ir Skandinavijos archeologijos centras, Šlèzvigas, Vokietija / Center for Baltic and Scandinavian Archaeology, Schleswig, Germany)

Prof. dr. Rimantas Jankauskas (Vilniaus universitetas, Lietuva / Vilnius University, Lithuania)

Akad. prof. dr. Eugenijus Jovaiša (Lietuvos mokslu akademija, Vilnius / Lithuanian Academy of Sciences, Vilnius)

Habil. dr. Bartosz Kontny (Varšuvos universitetas, Archeologijos fakultetas, Lenkija / Faculty of Archaeology, University of Warsaw, Poland)

Prof. dr. Valter Lang (Tartu universitetas, Estija / University of Tartu, Estonia)

Doc. dr. Algimantas Merkevičius (Vilniaus universitetas, Lietuva / Vilnius University, Lithuania)

Habil. dr. Tomasz Nowakiewicz (Varšuvos universitetas, Archeologijos fakultetas, Lenkija / Faculty of Archaeology, University of Warsaw, Poland)
Habil. dr. Grzegorz Osipowicz (Mikalojaus Koperniko universitetas, Torunè, Lenkija / Nicolaus Copernicus University, Toruń, Poland)

Dr. Gytis Piličiauskas (Lietuvos istorijos institutas, Vilnius / Lithuanian Institute of History, Vilnius)

Dr. Eve Rannamäe (Tartu universtitetas, Estija / University of Tartu, Estonia)

Dr. Andra Simniškyte (Lietuvos istorijos institutas, Vilnius / Lithuanian Institute of History, Vilnius)

Dr. Roberts Spirgis (Latvijos universitetas, Latvijos istorijos institutas, Ryga / University of Latvia, Institute of Latvian History, Riga)

Dr. Eugenijus Svetikas (Lietuvos istorijos institutas, Vilnius / Lithuanian Institute of History, Vilnius)

Dr. Andris Šnē (Latvijos universitetas, Ryga / University of Latvia, Riga)

Doc. dr. Gintautas Zabiela (Klaipédos universitetas, Lietuva / Klaipeda University, Lithuania)

Prof. dr. Šarūnas Milišauskas (Niujorko valstijos Bafalo universitetas, JAV / New York State University at Buffalo, USA)

Prof. dr. Timothy Chevral (Niujorko valstijos Bafalo universitetas, JAV / New York State University at Buffalo, USA)

Prof. dr. Johan Ling (Gioteborgo universitetas, Švedija / University of Gothenburg, Sweden)

Sekretorè / Secretary Dovilè Urbonavičiūtè-Jankauskienė

Redakcijos adresas / Editorial Board address:

Lietuvos istorijos institutas, Archeologijos skyrius

Kražių g. 5, LT-01108 Vilnius

Tel. (+370) 5 2614935, fax (+370) 52611433

e-mail: lietuvosarcheologija@gmail.com;

civilytea@gmail.com

\section{Žurnalas registruotas: EBSCO Publishing: Central and Eastern European Academic Source European Reference Index for the Humanities and Social Sciences (ERIH PLUS)}




\section{TURINYS / CONTENT}

Agnè Čivilytè

Agnè Čivilytè

Jonas Beran

Gabrielè Gudaitienè

Andreas Kotula, Henny Piezonka, Thomas Terberger

Vygandas Juodagalvis

Eglè Šatavičè

Grzegorz Osipowicz, Justyna Orłowska, Gytis Piličiauskas, Giedrẻ Piličiauskienė, Mariusz Bosiak

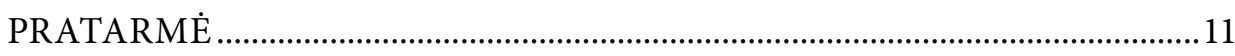

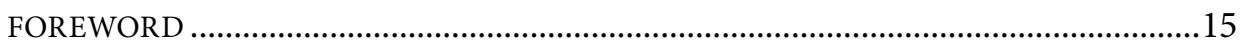

RUDENS POPIETĖ SU RIMUTE RIMANTIENE _.............................................19

AUTUMN AFTERNOON WITH RIMUTE் RIMANTIENĖ

GREETINGS FROM OLD CENTRAL-EASTERN GERMANY:

MEMORIES OF INTERESTING TIMES .27

LINKĖJIMAI IŠ PIETRYČIŲ VOKIETIJOS: PRISIMINIMAI APIE ĮDOMIUS LAIKUS

\section{STRAIPSNIAI / ARTICLES}

EIGULIAI, ONE OF RIMUTE் RIMANTIENĖ'S FIRST EXCAVATIONS A REVISED INTERPRETATION .33

EIGULIAI - VIENA PIRMŲJŲ RIMUTĖS RIMANTIENĖS KASINĖJIMŲ VIETŲ.

NAUJA INTERPRETACIJA

THE MESOLITHIC CEMETERY OF GROß FREDENWALDE (NORTH-EASTERN GERMANY) AND ITS CULTURAL AFFILIATIONS.......65 GROS FREDENVALDE (ŠIAURĖS RYTŲ VOKIETIJA) MEZOLITO LAIKOTARPIO KAPINYNAS IR JO KULTÜRINĖS SĄSAJOS .83

AKMENINIAI GLUDINTI KIRVIAI LIETUVOJE. TIPOLOGIJOS IR TERMINOLOGIJOS PROBLEMOS .85 GROUND STONE AXES IN LITHUANIA. PROBLEMS OF TYPOLOGY AND TERMINOLOGY 108

NEOLITHIC SOCIETIES AND THEIR POTTERY IN SOUTH-EASTERN LITHUANIA 111 NEOLITO BENDRUOMENĖS IR JỤ KERAMIKA PIETRYČIỤ LIETUVOJE. 142

OSSEOUS POINTS AND HARPOON HEADS FROM ŠVENTOJI SUBNEOLITHIC SITES, COASTAL LITHUANIA. FIRST TRACEOLOGICAL INSIGHT INTO THE WAY THEY WERE PRODUCED AND USED 147

KAULINIAI ANTGALIAI IR ŽEBERKLAI LIETUVOS PAJÜRIO ŠVENTOSIOS SUBNEOLITINĖSE GYVENVIETĖSE: GAMYBA IR NAUDOJIMAS PIRMU巳JŲ TRASOLOGINIŲ TYRIMỤ DUOMENIMIS 168 
Sławomir Kadrow

Frédéric Surmely

Rokas Vengalis, Jonas Volungevičius, Gintautas Vèlius, Albinas Kuncevičius, Justina Poškienè, Regina Prapiestienè

Andra Simniškytè

Inga Merkyte்

Rokas Vengalis
MACRO AND MICRO SCALE NEOLITHISATION PROCESSES IN SOUTH-EASTERN POLAND AGAINST THE BACKGROUND OF CENTRAL-EASTERN EUROPE 171

PIETRYČIŲ LENKIJOS NEOLITIZACIJOS PROCESAI MIKRO- IR MAKROLYGMENIMIS VIDURIO IR RYTŲ EUROPOS KONTEKSTE 187

CHARACTERIZATION OF TERTIARY FLINTS BY GEOCHEMISTRY: APPLICATION TO THE FRENCH TERRITORY.

TERCIARO TITNAGO PRANCÜZIJOS TERITORIJOJE CHARAKTERIZAVIMAS NAUDOJANT GEOCHEMINI METODĄ

ŽMOGUS PRIEŠ GAMTĄ: RELJEFO TRANSFORMAVIMAS İRENGIANT XIII-XIV A. KERNAVÉS PILI IR JO SUKELTI EROZINIAI PROCESAI ....... 207 MAN AGAINST NATURE: THE TRANSFORMATION OF THE RELIEF DURING THE CONSTRUCTION OF KERNAVĖ CASTLE IN THE $13^{\mathrm{TH}}-14^{\mathrm{TH}}$ CENTURIES AND THE EROSIONAL PROCESSES IT CREATED 248

KUPIŠKIO (AUKŠTUPĖNŲ) PILIAKALNIS: TEORINĖS PRIELAIDOS

IR TYRIMŲ REZULTATAI .255

HILLFORT OF KUPIŠKIS (AUKŠTUPĖNAI): THEORETICAL ASSUMPTIONS AND INVESTIGATION RESULTS 284

\section{KITAIP APIE ARCHEOLOGIJA /} ALTERNATIVE PERCEPTIONS OF ARCHAEOLOGY

Šarūnas Radvilavičius

KELIAUTOJO LAIKU UŽRAŠAI. 289

THE NOTEBOOK OF TIME TRAVELLER

\section{DISKUSIJOS / DISCUSSIONS}

STUDIES OF ANCIENT DNA. THE RACE FOR THE ULTIMATE ANSWER .293

SENOVĖS DNR TYRIMAI: KARŠTLIGIŠKOS ATSAKYMŲ PAIEŠKOS

\section{RECENZIJOS / REVIEWS}

ALGIMANTAS MERKEVIČIUS (SUD.), 2018. ANKSTYVOJO METALŲ LAIKOTARPIO GYVENVIETÉS LIETUVOJE (SETTLEMENTS OF EARLY METAL PERIOD IN LITHUANIA). 305

INFORMACIJA APIE PROJEKTUS / INFORMATION ABOUT THE PROJECTS 309

AUTORIŲ DĖMESIUI. 327 GUIDELINES FOR AUTHORS 


\title{
NEOLITHIC SOCIETIES AND THEIR POTTERY IN SOUTH-EASTERN LITHUANIA
}

\author{
EGLĖ ŠATAVIČE்
}

Vilnius University, Faculty of History, Department of Archaeology, Universiteto Str. 7, 01513, Vilnius, e-mail: archeologe@gmail.com

South-Eastern Lithuanian Stone Age pottery reflects the way of life, nutrition, social status, artistic expression, and intercommunity relationships of its creators and users. Natural conditions unfavourable for the survival of organic material and the intermingling of artefacts from different periods in sandy settlements limit the ability to precisely date and reconstruct the long, distinctive process of Neolithisation that began in the late $6^{\text {th }}$ millennium $B C$. Analysing the traces of ceramic vessel use, the structure of the pottery, the coiling and decoration technologies, their changes and reasons, it is possible to understand better the traditions of the Forest Neolithic communities and the encounters of different influences in SE Lithuania.

Keywords: Neolithic societies, SE Lithuania, potters, pottery, coiling, decoration, interaction between communities.

Pietryčiu Lietuvos akmens amžiaus keramika atspindi jos kūrèjų ir naudotoju gyvenimo būdą, mityba, socialinị statusą, meninę raišką bei santykius su kitomis bendruomenemis. Organikos išlikimui nepalankios gamtinès salygos bei ịvairiu laikotarpiu radiniu susimaišymas smèlinèse gyvenvietèse apriboja galimybes tiksliau datuoti ir atkurti VI tūkstantm. pr. Kr. pabaigoje prasidejjusį ilgo savito neolitizavimo procesą. Analizuojant molinių indu naudojimo pédsakus, keramikos struktūra, lipdymo bei ornamentavimo technologijas, ju pokyčius ir priežastis, galima geriau suprasti mišku neolito bendruomeniu tradicijas bei ịvairiu įtakų susidūrimus Pietryčiu Lietuvoje.

Reikšminiai žodžiai: neolito bendruomenès, Pietryčių Lietuva, puodžiai, keramika, lipdymas, ornamentavimas, bendruomenių tarpusavio sąveika.

\section{INTRODUCTION}

SE Lithuania was among the earliest Lithuanian regions which started to be investigated. Already at the turn of the $20^{\text {th }}$ century, flint finds and clay potsherds, which are decorated with various impressions, were collected on the sandy riverbanks and lake shores. The flint finds lying exposed on the ground's surface allow Stone Age settlements to be easily discovered but organic finds survive very poorly due to the sandy soil, and the surviving flint inventory and small potsherds are mixed up stratigraphically. It seems that the investigation of such settlements is nearly pointless because it is difficult to make connections between the discovered finds, to group them, or to determine their chronology.

The Stone Age discoveries in SE Lithuania are mainly related with the activities of Dr Rimute Rimantienè. She, together with her father, Konstantinas Jablonskis, in surveying this region, discovered many Stone Age finds and archaeological sites, led the majority of the $20^{\text {th }}$-century investigations of Stone Age settlements, published all of the investigation material, and, using various methods (the application of ceramic density measurements, stratigraphical analysis, planigraphy, and analogy searches) attempted to classify the finds into chronological groups and archaeological cultures and to determine 
their origin and development. The main aim of Soviet archaeology was the ethnic-cultural division of archaeological material on the basis of evolution theory and so the model, created by Rimantiene, for the development of the cultures and the appearance of the Indo-Europeans sufficed completely. The paradigm of the SE Lithuanian Stone Age, which was presented in her 1984 monograph Akmens amžius Lietuvoje has essentially remained unchanged to the present day (Rimantienè 1984).

It was expected that the perspective on the Stone Age in SE Lithuania would change after the restoration of Lithuanian independence with opening up of opportunities to become acquainted with theoretical models of archaeology and interdisciplinary investigation methods. In fact, the interdisciplinary projects realised during 19942001 yielded a large quantity of new investigation material, but it remained poorly interconnected and interpreted (Baltrūnas et al. 2001). The innovative biomolecular, isotope, and genetic investigations that have begun to be widely employed in recent years have allowed the lifestyles of the Stone Age people to be successfully reconstructed, but the SE Lithuanian material remains sidelined because it is mixed up and not very representative, burials not being encountered there, and the layers of charcoal residue needed for investigations being rarely discovered on pottery. Stone Age investigations of this region have mostly until now been limited to various methods of grouping and regrouping finds on the basis of chronological or cultural groups. The small potsherds discovered in that area usually do not have unique features and due to the mixing up of material from different periods, it is difficult to precisely date or reliably connect them with fireplaces suitable for radiocarbon dating.

Stone Age potsherds remain the most important source of information in attempting to understand the way of life of this region's communities, their interaction, and the influence of various factors in shaping their traditions. This article does not seek to deconstruct the established paradigms but somehow change the view of Late Stone Age material of this region by interpreting pottery through the prism of its creators and users and encouraging thinking in somehow untraditional directions.

\section{THE CERAMIC MESOLITHIC, SUBNEOLITHIC OR NEOLITHIC?}

The concept of 'Neolithic' was initially connected with the material culture: exquisite, frequently polished stone tools of various shapes (Lubbock 1865, p. 60). Representatives of the German cultural-historical paradigm also assigned similar items to the Neolithic, accenting Neolithic pottery as the most important indicator in distinguishing cultures, which in turn reflect ethno-linguistic groups (Kossina 1911, p. 1112). Even in the late $19^{\text {th }}$ century it was observed that economic rather than technological development is more important. This perception was especially confirmed in the context of Childe's 'Neolithic revolution' (Childe 1936). The discovery of a production economy and its inseparable components: domestic plants and animals, large buildings, group villages, spinning and weaving, and finally pottery and polished axes became the main criterion for the Neolithic. An attempt was made to apply this advanced 'Neolithic packet' in describing the material culture of not only all European, but also SW Asian Neolithic communities, despite their diversity (Çilingiroğlu 2005).

A different conception of Neolithisation was generated not only by the different processes that occurred in various parts of Europe, but also by the uneven distinction of the essential Neolithic features. Archaeologists in the Soviet Union (which included Lithuania, Latvia, and Estonia) essentially continued the traditions of cultural-historical archaeology and accented the shift in the material culture. In the absence of clearer signs of economic changes, the beginning of the Neolithic was connected 
with the emergence of pottery, as part of the same Neolithisation process or the earlier development of agriculture (Rimantienè 1984, p. 107).

Representatives of the processual school accented environmental determinism, the demographic pressure caused by a sedentary lifestyle, and the influence of the diversity of the food resources in selecting a 'calorie-seeking' strategy. For example, the intense exploitation of aquatic resources led to a sedentary lifestyle and could have been an intermediate step towards agriculture, but readily available alternative non-plant food resources and the domestication of animals could have intensified the production of non-plant food, as a more nutritionally important resource (Binford 1983, p. 212-213).

Post-processual archaeology, unlike social archaeology, values symbols over economic factors. It accents the opposition between domus (Lat. home) and ager (Lat. field, outside the domus) or agrios (Gr. wild, savage). Up until the Neolithic only agrios existed, the Neolithic being associated with 'agri-culture', i.e. 'culturing the wild' or the process of social and cultural domestication (Hodder 1990, p. 86). Not only large settlements with long buildings, but also tombs, mounds, and other burial monuments are considered domus symbols. The different interpretation of ceramic symbols in different contexts should be noted. A strong link between women, the house, the oven area, and pottery can be seen in the agricultural societies of SE and Central Europe (Hodder 1990, p. 65), while in South Scandinavia, domus symbols are more associated with burial monuments and pottery decoration is linked to its role in public rituals (Hodder 1990, p. 208). In Lithuanian territory, despite the predominant agrios, including flexibility, individual mobility, and the use of wild resources, the prevailing symbols change with the emergence of pottery. While the representative symbols of societies during the Palaeolithic are reflected by various flint arrowheads and during the Mesolithic by bone-horn artefacts, with the emergence of pottery the way of life, traditions, and worldview of communities are reflected in the production, ornamentation, and functional purpose of their pots.

Decoding the symbols helps to better perceive the social-cultural processes that occurred in the Neolithic societies, but it offers few explanations for the reasons for the changes. The social theory of structuration, which is based on an analysis of the habitus-agency interaction, i.e. an agent's activity within the social system, space, and time, is important in attempting to explain the Neolithisation processes that occurred in the E Baltic region. According to the 'structuration' theory, the dynamics of the pottery craft could be understood as a specific form of structured knowledge, transmitted through the routines of daily practice, and modified by the strategic interventions of group or individual agency (Jordan, Zvelebil 2009, p. 67). A thoroughly reasoned 'structuration' theory has been applied to the Baltic region through a unified model for the governing dynamics of agricultural frontier zones (Troskosky et al. 2019). The adoption of agriculture is explained by the model of punctuated equilibrium and the reaction of different communities to innovations and the need to change are associated with different levels of the stress affect. Although it has been noted that in E Lithuania, like in Latvia, as CWC influence fades c. $2400-1800 \mathrm{BC}$, the old traditions of the Narva culture reappear, but broader interpretations of this phenomenon have not been presented (Troskosky et al. 2019, p. 153). The reappearance of old traditions in pottery can also be seen in SE Lithuania. Migrations can hardly explain this, a return to a previous safe mode after the stress affect level fell being more likely. It is unfortunate that in this model, not only the agricultural frontiers in the SW, but also encounters with pastoral communities to the E and SE, which can be seen in SE Lithuania, remain unevaluated.

The influence of this direction can perhaps be connected with the work of Zvelebil in analysing 
the role of hunter-gatherers in the Baltic region in the context of its Neolithisation. It recognises the possibility that in the past well-established and economically viable hunter-fisher-gatherer communities could have also existed near agricultural communities. Products of agricultural activities, status items, and partners could have reached the hunter-gatherers through a lively network of interaction and exchange. Ultimately the evaluation was made that due to the agency of local huntergatherers the Neolithisation process is a much more varied and diverse phenomenon than had been previously thought (Zvelebil 2001).

Zvelebil's diffusionist model of Neolithisation became especially popular in independent Lithuania. It attempts to distinguish the phases of the availability model for the transition to farming. The beginning of the Neolithic is connected with both palynologist data about domesticated plant pollen in the $5^{\text {th }}$ millennium $\mathrm{BC}$ and with the radiocarbon dates, c. $5500 / 5300$ вс, of the Katra 1 settlement fireplaces, beside which the earliest pottery has been discovered (Antanaitis-Jacobs, Girininkas 2002).

This model of Neolithisation in Lithuania has been criticised in recent years after the reliability of the palynological and macrobotanical data as well as the radiocarbon dates came into doubt due to the freshwater reservoir effect and the possibilities of associating pottery to fireplaces in sandy settlements (Piličiauskas 2016). In fact, new dates from the Zvidze Neolithic settlement (Latvia) ( $5500 \mathrm{cal} \mathrm{BC)} \mathrm{and}$ food crusts from early pottery from Lučyn Barok Siamionaŭski (Belarus) (5200-5000 BC) (Courel et al. 2020, Electronic supplementary material, Fig. S3), allow one to state that pottery could have appeared in SE Lithuania by at least the late $6^{\text {th }}$ millennium BC.

The latest DNA studies, which shows the demographic composition of Europe was changed by a massive migration, seems to refute the theories of moderate cultural diffusion and steady development (Haak et al. 2015). The nationalistic theory, inherited from the late $19^{\text {th }}$ century, of the bellicose mounted warriors of the Black Sea's Yamnaya culture, who brought corded ware and Indo-European language with them, has been resurrected again (Kristiansen et al. 2017). Such a fairly forthright DNA connection with language, culture, way of life, and corded decoration is perhaps an example of what happens when an attempt is made to explain cultural social processes through natural sciences. Although in recent years the interdisciplinary investigations of archaeological material have reached new heights, archaeological theory is regressively returning to ideas espoused by culture-historical archaeology (for more, see Furholt 2018).

It is precisely with the migration of the GAC and CWC that an attempt has been made in recent years to connect it with the beginning of the Neolithic in Lithuania, basing it on DNA, stable isotope data, and pottery lipid residue analysis. It has been proposed that the previously existing communities that used pottery be called 'Subneolithic' (Piličiauskas 2016) or in accordance with the Scandinavian and Estonian archaeological example, assigned to the 'ceramic Mesolithic' (Kriiska et al. 2017). Such terms are acceptable and would seem logical for Central and W European countries, in which the Neolithic is clearly connected with the agricultural Linear Band Pottery culture and TRB.

The attempts in the E Baltic region and postSoviet countries further to the East to connect the beginning of the Neolithic with the emergence of pottery in hunting communities frequently appear to be behind the times. Nevertheless in recent years it have been noted that E European material is in fact little recognised and that a unique East-European type of Neolithisation scenario exists. In the second half of the $6^{\text {th }}-5^{\text {th }}$ millennia BC, hunter-gatherers in the SE Baltic region, who had only rare contacts with farmers, accepted 'ceramisation', an event that was independent of the 'Agrarian Neolithic'. In the $4^{\text {th }}$ $3^{\text {th }}$ millennia $\mathrm{BC}$ not only can intensive interaction be 
seen, but also the 'Forest Neolithic' society (which is connected with the Nemunas culture) so expanded the boundaries of its influence that in the south it reached to nearly the Carpathian Mountains and in the west the right bank of the Oder. It is thought that the 'Forest Neolithic' traditions were willingly adopted by TRB communities because of their cultural closeness to the E European Mesolithic hunter-gatherer societies as opposed to the 'foreign', central European Neolithic societies (Nowak 2009). Perhaps such a closeness inherited from the Mesolithic can better explain the CWC formation processes and genetic admixtures that occurred in present-day Polish territory (Linderholm et al. 2020).

In employing the term, 'Subneolithic', it is important to understand that a Subneolithic (ProtoNeolithic or Para-Neolithic) society was not the same Mesolithic society, just now producing and using pots, nor was it a transitory stage between the Mesolithic and the Neolithic. It was a community with a specific social structure, ideology, and economy, which deliberately and selectively adopted and internally remodelled some traits of the hunter-gather and farmer lifestyles. This process can be called an 'alternative model of Neolithisation' (Józwiak 2003).

In the E Baltic region, the natural environment, it appears, was especially deterministic. The sands of SE Lithuania, unlike the fertile loams of S Poland, could hardly be expected to become the foci of such successful agriculture, but, considering the possibilities of contacts, the likelihood should not be rejected that a basic knowledge about Triticum sp. or Hordum vulgare also existed there, and the individual Cerealia-type pollen grains in palynological samples may perhaps also represent the first completely unsuccessful attempts to cultivate domesticated crops. In fact, the migration of the so-called CWC also did not bring a complete 'Neolithic packet' to the E Baltic region. Agriculture became established there only during the Final Bronze Age. Marked social changes, population growth, and the formation of fortified settlement sites can be seen at that time (Motuzaite Motuzaviciute 2018). Thus, the Neolithic in the E Baltic region cannot be defined in general by attempting to statistically apply the Neolithic economic criteria characteristic of $\mathrm{W}$ and Central Europe. The term, 'Subneolithic' confers a derogatory aspect accenting primitiveness, but without explaining the processes that were occurring. It is difficult to evaluate the diversity of the NE European pottery communities with their various non-agrarian traditions after they have been placed in a common Subneolithic kettle.

In searching for terms to describe the processes that occurred in Lithuanian territory during the late $6^{\text {th }}-2^{\text {nd }}$ millennia $\mathrm{BC}$, it appears the concept of environmental deterministic 'Forest Neolithic', which has been fairly successfully applied to Lithuania, is more acceptable. In the forested regions of $\mathrm{E}$ and $S$ Lithuania, more abundant remains of the Narva and Nemunas cultures, which are ascribed to the Forest Neolithic, can be seen, while in the more fertile areas of Central Lithuania more abundant signs of Agrarian Neolithic cultures: GAK, CWC, or even the earlier TRB can be expected (Brazaitis 2005). Finally although the Middle Neolithic classic Nemunas culture is traditionally assigned to the circle of Subneolithic cultures, it is thought that it formed as a consequence of collaboration between huntergatherers and the TRB c. 3800/3700 вC (Józwiak 2003). Thus, the beginning of the Neolithic can be seen in the classic Nemunas culture traditions, which already reflect clear changes.

All of the aforementioned theories of different directions are relevant in analysing the Late Stone Age communities of SE Lithuania, and their application allows one to better perceive and interpret the transformations that occurred there. Despite the attempts of some authors to more precisely define the concept of 'Neolithic', this article retains a broad definition of the term, 'Neolithic' in an attempt to convey the diverse developmental processes, which 
are observable from the late $6^{\text {th }}$ millennium $\mathrm{BC}$ and are best reflected in the pottery.

Perhaps the most accurate concept of the 'Neolithic' of the E Baltic region has been defined in an Estonian and Finnish archaeological study:

'Neolithic can be considered only as a kind of "metaconcept" - a heuristic term that gives only a very approximate reference of the time period and (cultural) context, for which the actual time frame and content should be determined separately in each case. [...] in addition to the long-standing technical, economic and environmental determinism, socio-cultural and cognitive aspects are of key importance for characterizing the entire spectrum and the variability of the Neolithic transformations.' (Нордквист, Крийска 2018, р. 172)

\section{THE EMERGENCE OF POTTERY IN SOUTH-EASTERN LITHUANIA}

The emergence of clay vessels can be connected with a practical need to have warm, liquid, more easily digested food, to demonstrate identity and status in social life, as well as with aesthetic artistic expression using materials, which were easily found in the nearby environment. Many well understood reasons as well as diverse, difficult to perceive ones influenced the emergence of pottery, but this did not occur at one focus. For a long time, pottery was considered an inseparable part of the 'Neolithic packet', which arrived from the Near East, but after the E Asian material began to be analysed more broadly it was noticed that beside the 'Western' variant of the Neolithic exists an alternative 'Eastern' Neolithic, i.e. an independent emergence of pottery among hunting and gathering societies not associated with agriculture. Regression models have estimated the average rates of pottery technology spread in space and time on the basis of the radiocarbon dates for the pottery that first emerged in Eurasia and Africa. $\mathrm{N}$ Europe is clearly distinguished, the Caucasus crossing boundary dividing the European data into a southern zone associated with early agriculture and a northern zone associated with East Asia traditions of hunter-gatherer pottery. Along this frontier both traditions merged (Jordan et al. 2016). SE Lithuania, like the entire Baltic region, belongs to the East Asiaderived traditions of hunter-gatherer pottery, but it is near the frontier.

The sparsely decorated pots that began to be produced in the upper reaches of the Volga in the first half of the $7^{\text {th }}$ millennium $\mathrm{BC}$ are considered to have been the source of the Baltic region's pottery. Through mutual contacts the traditions for the production of this pottery reached the E Baltic region c. $5500 \mathrm{BC}$ and led to the start of the of the Neolithic Narva culture ${ }^{1}$. The earliest Dubičiai-type pottery, which is associated with influence from the SE, i.e. the Dnieper-Don culture, which was found to the north of the Black Sea, has been discovered in SE Lithuania. Both of these very early pottery traditions influenced each other's development and the emergence of Ertebølletype pottery in the SW Baltic region (Piezonka 2015).

The sherds of organic-temper pottery, undecorated or decorated with various-sized pits, that are found in many SE Lithuanian Stone Age settlements are usually assigned to Dubičiai-type pottery, but they can also be considered to be close to the traditions of the Narva culture. The very earliest pottery had perhaps not acquired clear features and performed only a functional purpose, but in becoming representational through the use of the symbols of the communities, both the pot shapes and decorations acquired individual features.

\footnotetext{
1 The article's author understands that the names of cultures are artificially created and can be disputed. Despite the critics, these names have long been established in literature. The archaeological cultural names created by Rimantiene are useful and justified in attempting to abstractly define the differences in the lifestyles and worldviews of communities in time and space.
} 
In attempting to explain the spread of pottery, migration theories alone are insufficient; a globalisation process can be seen. An expansive interaction through the adoption of early pottery allows the conclusion to be drawn that the makers of early pottery were very mobile and that the spread of pottery likely occurred within existing networks established in the Upper Palaeolithic. Separated by long distances, distant communities maintained networks of interaction where ideas, styles, cultural behaviours, and other socio-economic and technological transformations spread through natural corridors of communication (Hommel 2018). Authors previously strove in archaeological literature to strictly define the chronological and spatial boundaries of archaeological cultures and to clearly distinguish their individual features, but it has recently become clear that it is more important to examine archaeological material for tendencies for development through interaction rather than for regional differences.

\section{THE STONE AGE POTTERY OF SOUTH-EASTERN LITHUANIA}

The absolute majority of the SE Lithuanian Stone Age pottery has been discovered in Varèna District: in an area of fluvioglacial lowlands created by the last glaciation, the Dainava, to the $S$ of the River Merkys, or near it. The Dubičiai microregion, which has been investigated the most broadly and contains the best known settlements (Barzdis Forest, Dubičiai 1-3, Gribaša 4, Karaviškès 6, Katra 1-2, Katros Ištakos, Lynupis, Margiai, and Šakès) that are situated situated on the shores of large lakes that existed during the Neolithic (Marcinkevičiūte 2016). The areas around Lakes Grūda (Kabeliai 23), Glūkas, and Varènis Glūkas, Varènis (Glūkas 3, Varènè 10) have also been broadly investigated (Fig. 1). All of the investigated settlements were sandy, multi-period, unstratified sites. In comparing the
Dubičiai microregion settlements with the Narva culture settlements that existed on huge Lakes Kretuonas (Švenčionys District, E Lithuania) and Biržulis (Telšiai District, W Lithuania) on the basis of pottery quantities, it is seen that far less pottery was used in SE Lithuania, but the pottery that was used was somewhat more diverse and is found over a broader area. This is perhaps connected with a lower population density in SE Lithuania, greater short-distance mobility, or lesser need for pottery in the home, but it was probably also caused by the unfavourable conditions for the survival of archaeological material in sandy settlements.

The Stone Age pottery discovered in SE Lithuania is usually quickly divided up on the basis of the archaeological cultures: with organic temper - the Dubičiai-type or Pripyat-Neman culture; with ground stone temper - the Nemunas culture; with sand temper and corded impressions, pinching, or an incised fishbone motif - the CWC. But all of this ceramic individuality is more a reflection of the convergence of influences from several different traditions in the territory of SE Lithuania. As a consequence, in analysing Stone Age pottery, this article has tried to make very cautious use of cultural terms, which, in any case, reflect a direction of influence rather than a boundary. Ceramic traditions are dynamic processes, which are unable to spread pell-mell across cultural and social boundaries but can transform and develop through interaction between communities as well as through agency inside the community. In analysing SE Lithuanian pottery, an effort has been made to evaluate it not just as the result of the influence of other communities, but also to note the agency of the vessel's creator/user in forming traditions and rules of behaviour, his/her status in the society, and his/her relationship with his/her surroundings, and to understand the reasons for his/her choices.

The Stone Age pottery was analysed and described on the basis of the following criteria: 


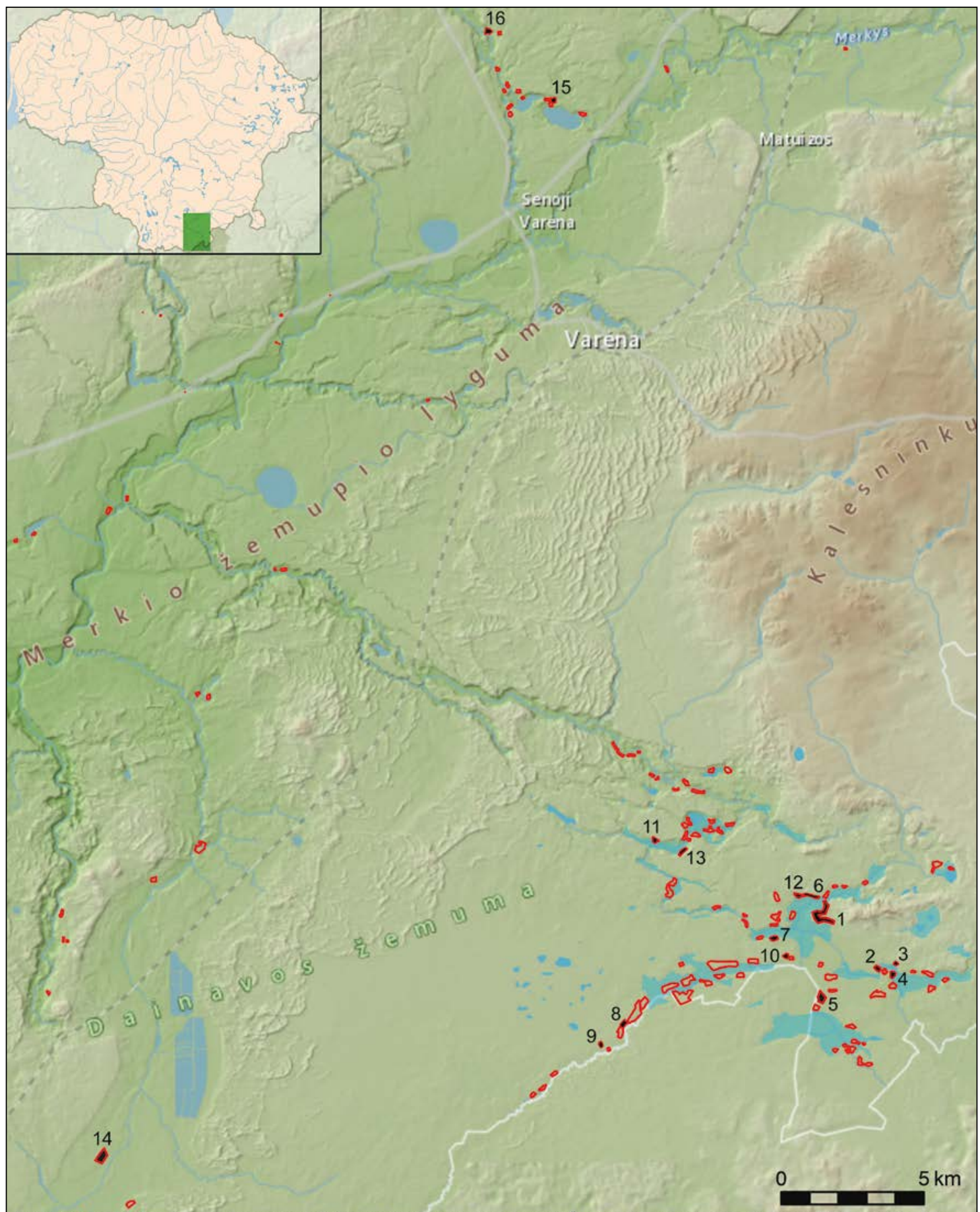

Sukürè: (- UAAB HNIT BALTIC. Duomenys: () Nacionaliné žemès tarnyba prie Žemès ükio ministerijos, (c) F. Kavoliute (2012). Lietuvos gamtinis pamatas. I dalis: gelmés ir paviršius, (c) F. Kavoliute (2000). Naujieji Lietuvos orografiniu vienetu pavadinimai, (c) Vietovardžiu żodynas. () UAB Hnit-Baltic, 2014; ORT10LT (c) Nacionaline Žemes Tarnyba prie ŽUuM, 2012-2013

Fig. 1. A map of SE Lithuanian Neolithic settlements (marked in red). Sites mentioned in the article: Dubičiai Microregion (1 Barzdis Forest 1;2 - Dubičiai 1;3 - Dubičiai 2; 4 - Dubičiai 3; 5 - Dubičiai-Draciliškè; 6 - Gribaša 4; 7 - Karaviškès 6; 8 - Katra 1; 9 - Katra 4; 10 - Katros Ištakos; 11 - Lynupis; 12 - Margiai 1; 13 - Šakès); Lake Grūda Microregion (14 - Kabeliai 23); Lakes Glūkas, Varènis Microregion (15 - Glūkas 3; 16 - Varènè 10). Drawing by E. Šatavičè. 
- plastic raw materials and temper;

- preparation of the clay body (porous, ordinary, or compacted) and the coiling method;

- the preparation and smoothing of the vessel's interior and exterior surfaces;

- sherd thickness, which allow the vessel's size and form to be preliminarily determined;

- decoration.

An attempt was also made to describe the firing method and the vessel's use, but due to the erosion of the sherds that had lain in sandy soil it is difficult to see the interior structure. The black stains visible on the surface of pottery fired in an uncontrolled oxidation atmosphere are difficult to distinguish from the soot that collects on a vessel when it is used for food production in an open fire. Due to the effect of the destructive environment, it is rare to find sherds, which display faint signs of charcoal residue, and, compared to the pottery with thick layers of charcoal residue that is found in settlements on the peaty areas around Lakes Kretuonas and Biržulis to the north, it is possible to form the impression that SE Lithuanian pottery was never used.

This article presents initial general observations about SE Lithuanian Stone Age pottery and detailed descriptions of the sherds; photographs of both surfaces and the profiles have been assembled in a sherd database, which will be published at $<$ www. neolitas.eu $>$. The flexible search system, which allows for the combination of different criteria and the possibility of visually comparing and grouping the sherds, with allow users to become better acquainted to the diversity of the pottery and to determine its development. It is hoped that such accessibility will encourage not only archaeology students and members of the public, who are interested in their cultural heritage, to take an interest in this region's pottery and to analyse it but also encourage foreign investigators to compare our region's pottery with material from their lands and to create similar online databases elsewhere. In comparing pottery in the context of the neighbouring countries, the influence of present-day state borders is frequently felt in the interpretation of the material and thus, by creating similar online databases, it would be easier to perceive tendencies in the spread of ceramic construction traditions in space and time.

In order to more precisely determine the characteristic methods for creating the clay body, coiling, and firing, the investigation of a fresh break or cross-section on a sherd yields a more comprehensive and reliable image. This is, in fact, a destructive method and therefore it can be carried out only after an evaluation of the usefulness of the investigation. Twelve sherds that demonstrate different coiling traditions and come from settlements investigated by Rimantienè during 1980-1985: Margiai 1 (5 sherds) (Rimantienè 1999a), Barzdis Forest (4 sherds) (Rimantienè 1999b), and Šakès (3 sherds) (Rimantienè 1992) were used for the investigation. The surfaces, cross-sections, and polished sections of these sherds were examined using a stereo microscope and a structural and chemical analysis was made using SEM-EDX, FTIR, XRD, and XRF. (The preparation of separate articles about these investigations has begun.)

\section{POTTERY PRODUCTION}

\section{Preparation of the clay body}

Ceramic production starts with the selection of the plastic raw material. SE Lithuania is characterised by sandy soils with clay rarely being found on the surface. It was previously thought that pots were produced from varved glacial clays, which were exposed by the wind blowing away the thin layer of aeolian sand covering them. The use of varved clay is shown by an absence of diatoms in the potsherds (Kriiska 1996), but it is unlikely that varved clays were easy to access in SE Lithuania. In realising the 1994-1997 project, The Stone Age in South Lithuania 


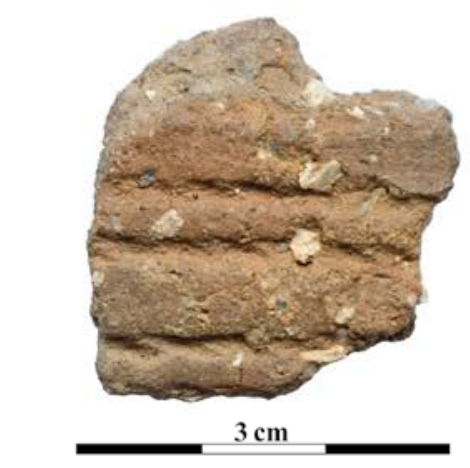

1.
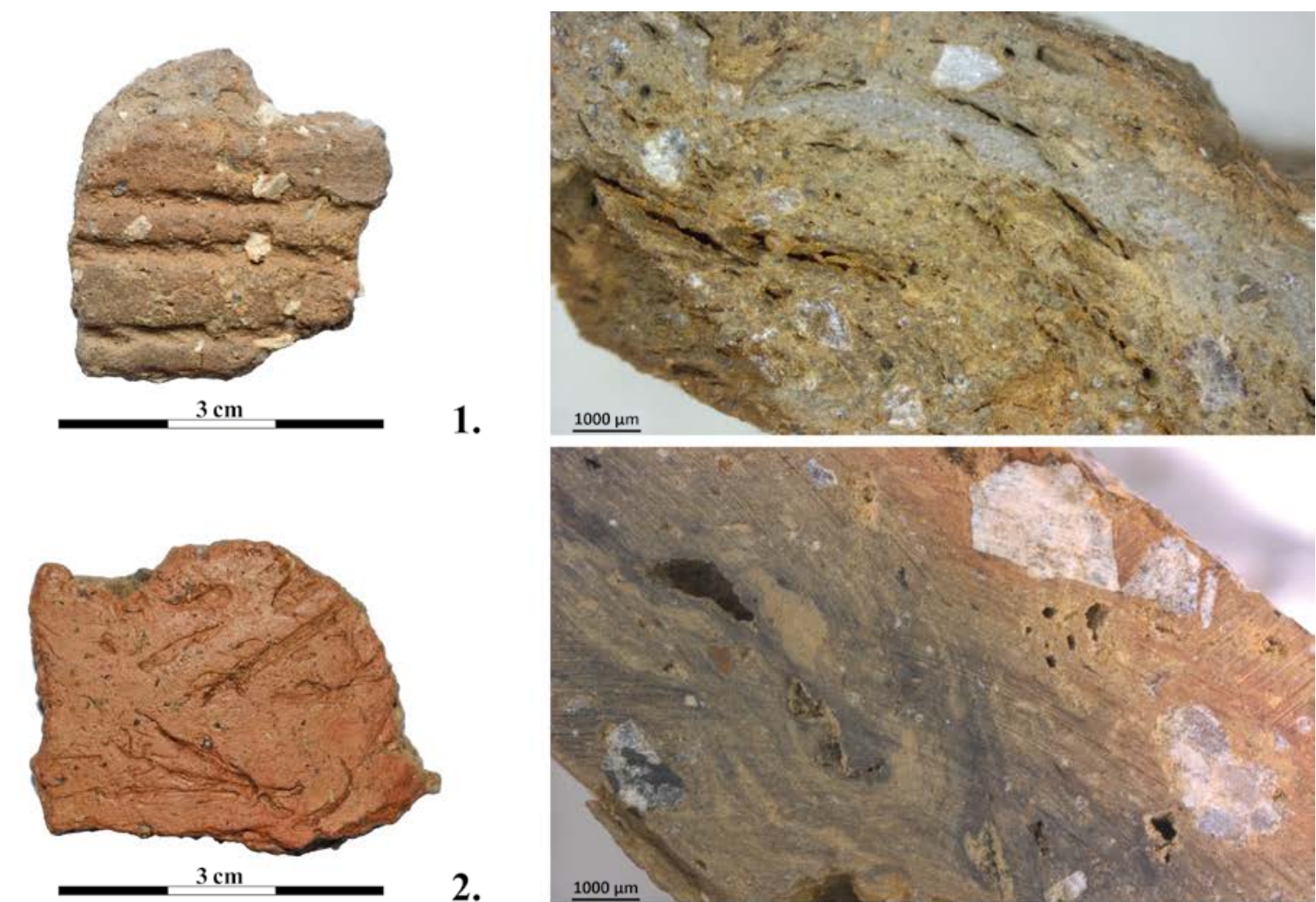

2.
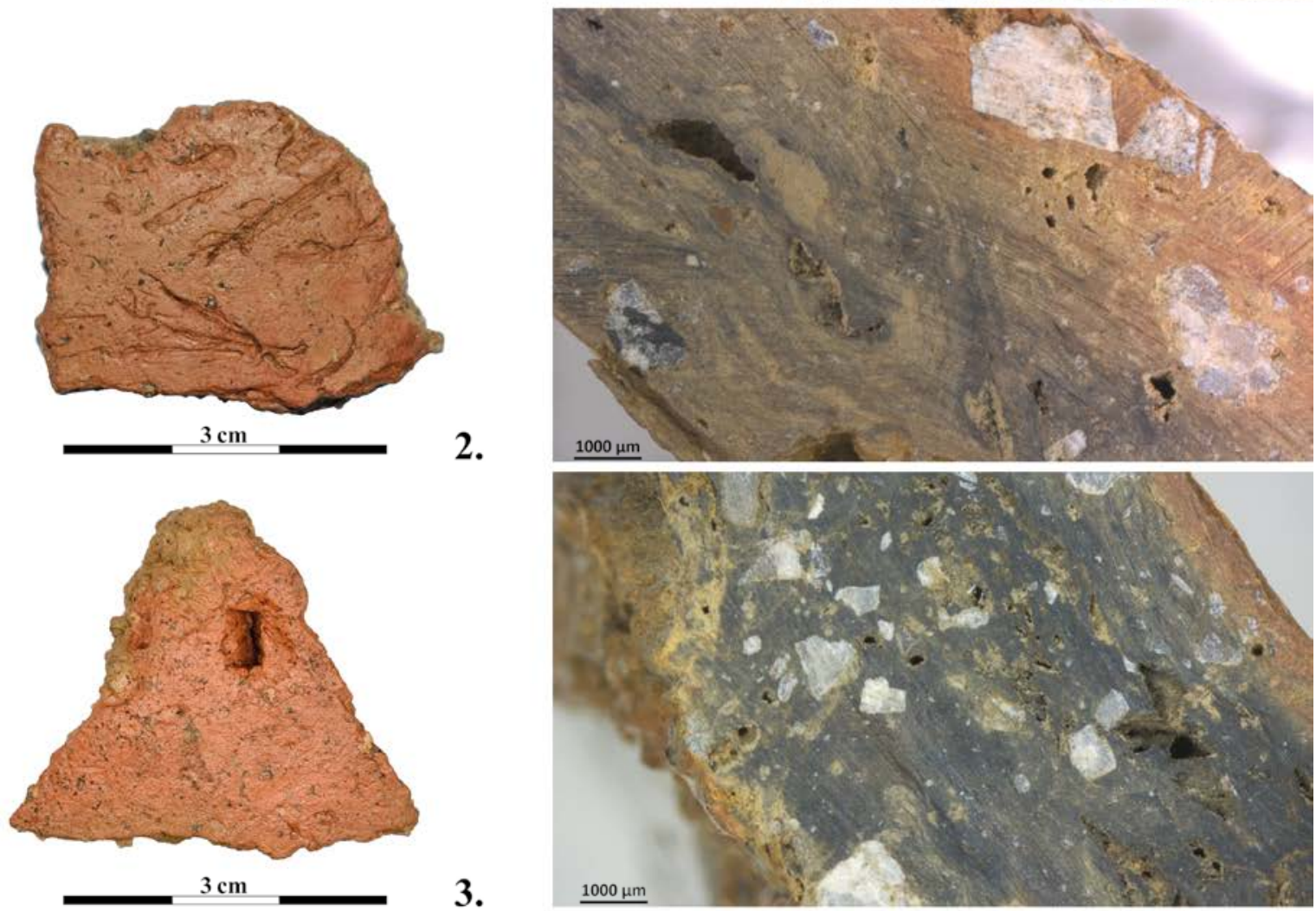

3.
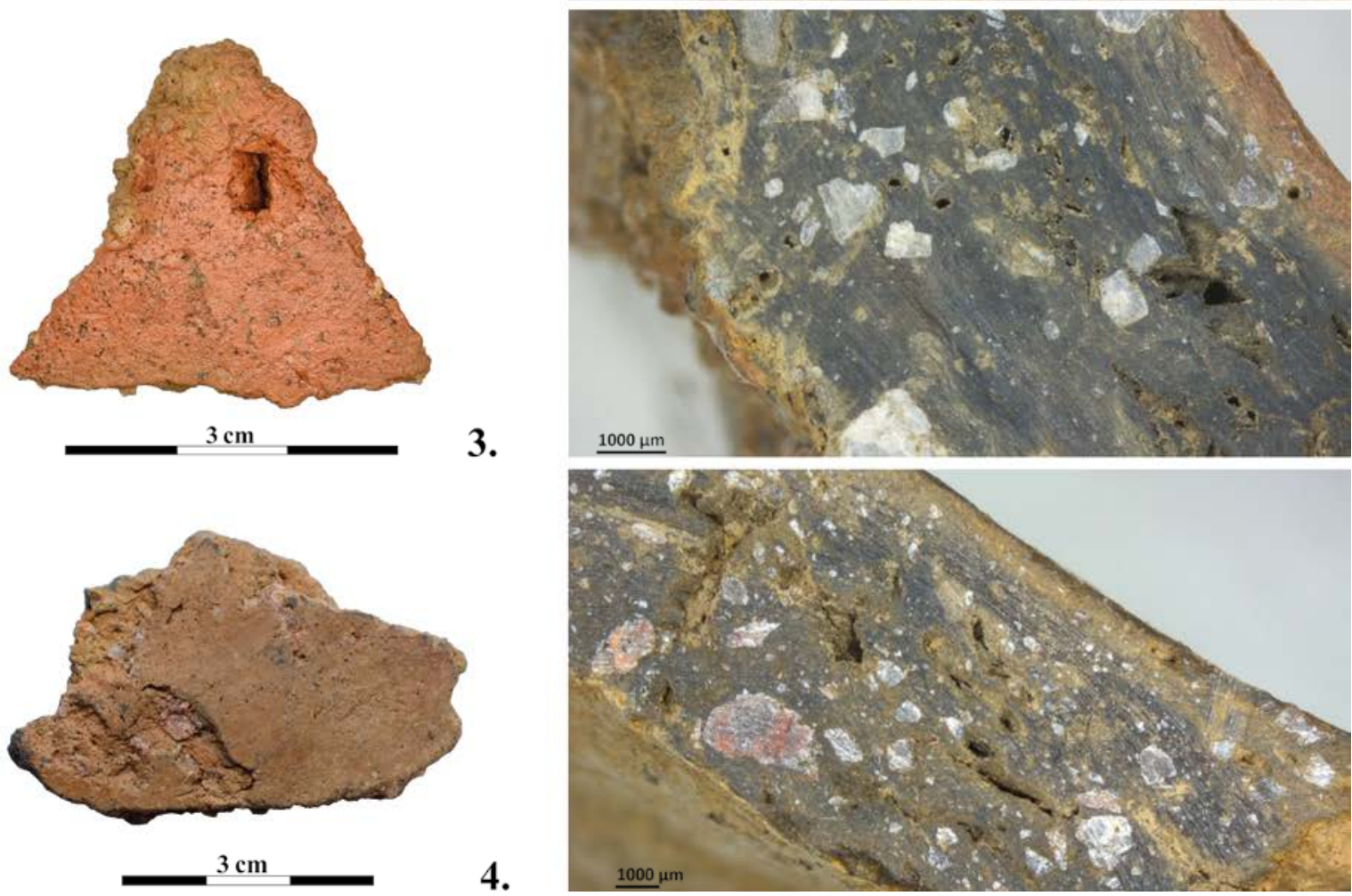

Fig. 2. The layering of the clay body and traces of various-sized organic material visible in the cross-sections of sherds with mineral temper: 1, 4 - Margiai 1; 2, 3-Barzdis Forest 1. Photos by E. Šatavičè. 

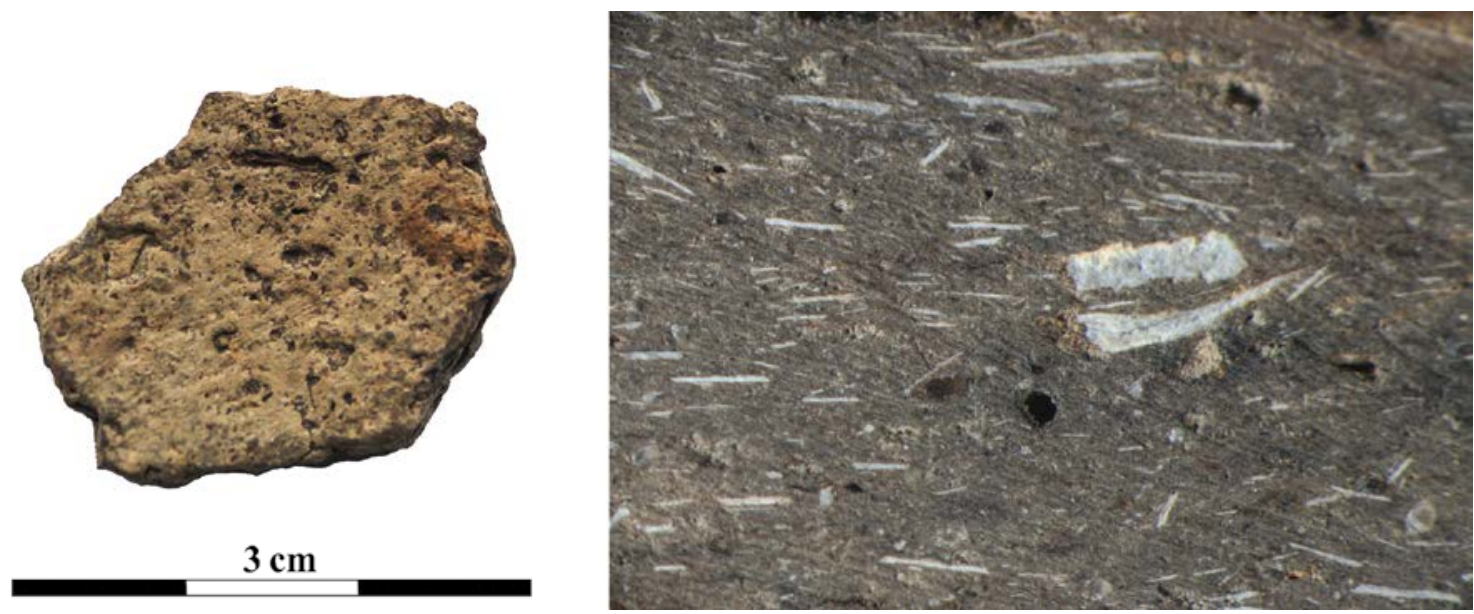

Fig. 3. A Dubičiai-Draciliške settlement sherd with ground shell temper and the sherd's cross-section. Photos by S. Širvydaité-Šliūpiené.

(According to Geological, Palaeogeographical and Archaeological Data), an attempt was made to discover sources of clay near Stone Age settlements and to compare the geochemical composition similarities of these clay pits and Neolithic pottery (Taraškevičius et al. 2013). These investigations appeared to be promising but they were of no interest to archaeologists at that time and now that the technology has improved considerably, they should be redone. The origin of the clay resources is important not only in attempting to determine whether pots were produced locally, but also in order to appreciate how much time and effort the preparation of the clay body required.

An analysis of the breaks and cross-sections of sherds from SE Lithuania frequently exposes the layering of the clay body and traces of varioussized organic material, even in sherds with mineral temper (Fig. 2), also round particles of fine clay and considerable quantities of rounded sand grains. These features are characteristic of silt from shallow waters (rivers or lakes) (Bobrinsky, Vasilyeva 2012). It is unlikely that the earliest SE Lithuanian pottery, i.e. that with organic temper, was made from pure silt, but it is likely that it was made from natural silty clay raw materials found on the edges of lakes and rivers without any added temper.
In analysing the general evolution of the pottery it can be seen that earlier traditions indirectly influenced the development of new tendencies, e.g. old clay body elements are imitated when the source of the raw material changes. It is known from ethnographic material that when potters move to a region where their traditional raw materials are not available, they begin to replicate these materials artificially by adding sand, broken rock, broken shell, or other kinds of temper to the clay paste. The inclusion of ground shell, dung, or plant temper can be considered a later replacement for lacustrine silt (Bobrinsky, Vasilyeva 2012, p. 73). Ground shell temper is more characteristic of the Narva culture tradition, but it is also encountered in SE Lithuania, for example in the Dubičiai-Draciliške settlement (Šatavičius 2006) (Fig. 3). Large shallow lakes existed in the Dubičiai microregion during the Neolithic. In the similar microregions of Kretuonas (Švenčionys District) and Biržulis (Telšiai District) the abundant legacy of the fishing communities with Narva culture traditions allows one to expect that a network of communities, which were close to the 'Narva' tradition and were exploiting water resources, also existed in the vicinity of Dubičiai (Marcinkevičiūtè 2016).

Previously all pottery with organic temper from SE Lithuania was ascribed to the early Dubičiai-type 


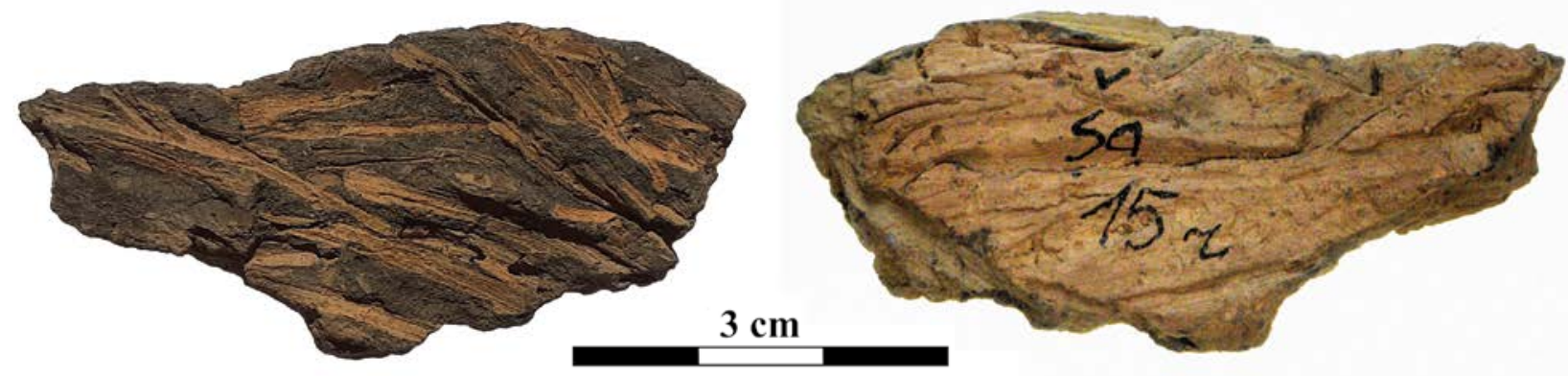

Fig. 4. Long leaves visible in a break on a Dubiškiai-type sherd (Šakès settlement). Photo by E. Šatavičè.

1.

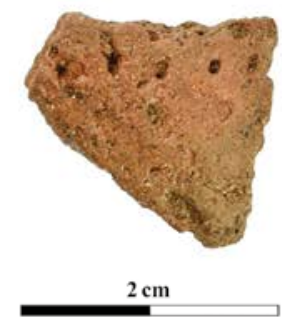

2.

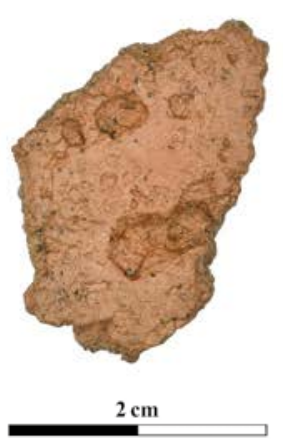

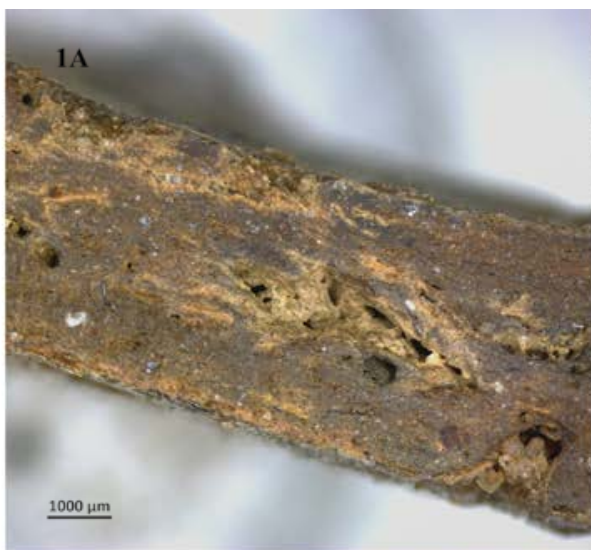
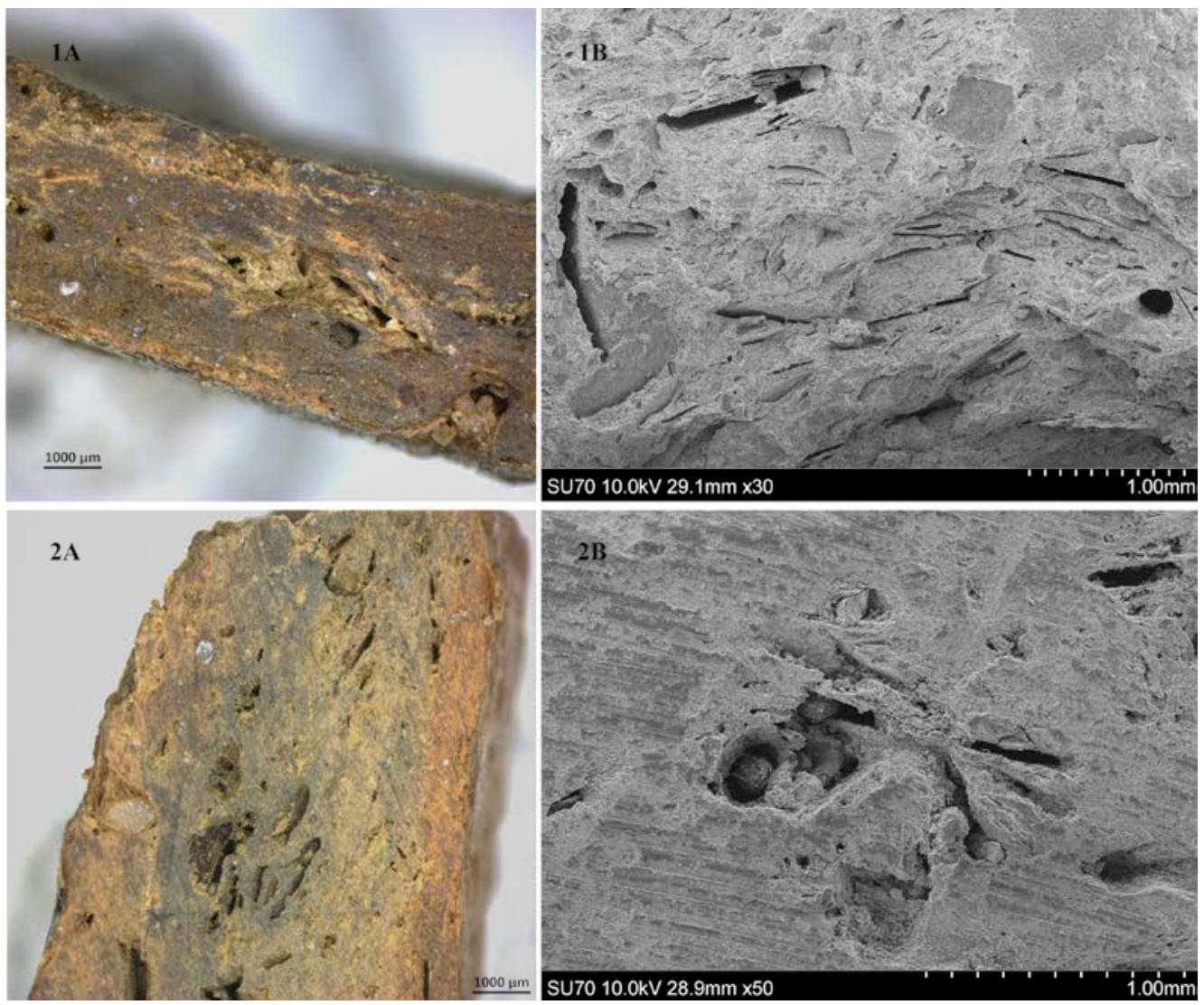

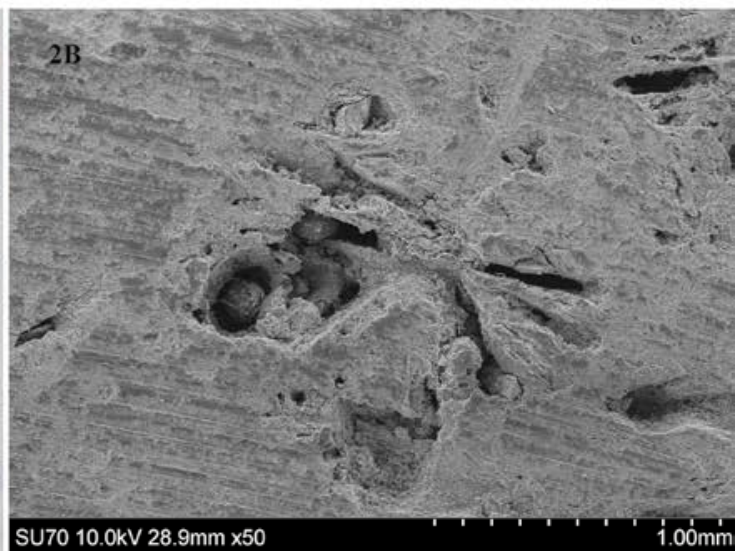

Fig. 5. Grass spikelet traces visible in the cross-sections of sherds from the Barzdis Forest settlement as seen using a: $1 \mathrm{~A}, 2 \mathrm{~A}-$ stereomicroscope; 1B, 2B - SEM). Photos by E. Šatavičé, SEM photos by R. Vargalis (Vilnius University Institute of Chemistry)

pottery of the Nemunas culture or to a separate Dubičiai culture (in Belarus to the Pripyat-Neman Culture) (Tkachou 2018), but the pottery is extremely diverse and poorly understood. The plant species, the part of the plant used, and the piece size all differ and it is not clear whether specially harvested plants or detritus were used. Without more detailed experiments, it is difficult to say whether the long leaves frequently encountered in Dubičiai-type pottery (Fig. 4) belong to some member of the terrestrial Poaceae family or to the aquatic Stuckenia pectinate (syn. Potamogeton pectinatus) (Kulkova, 
Kulkov 2016). The preparation of clay body with plant temper also differs. The earliest pottery with plant temper is porous and fairly crude while, for example, the thin-walled pottery with a compacted clay body discovered in the Barzdis Forest settlement can more likely be dated to the end of the late Neolithic. The plant temper seen in the cross-section of this latter pottery consists of not only leaves but also perhaps some pieces of a Poaceae spikelet (Fig. 5). It is interesting that in S Poland, the thin-walled pottery of the LBK was also made using silty clay with plant temper, i.e. various pieces of cereal plants (Triticum sp., Hordeum vulgare), mostly chaff (Moskal-del Hoyo et al. 2017). The inclusion of organic temper in a clay body was probably connected not only with cultural traditions but also early ware with positive practical features: vessel lightness, increased strength due to the fibrous components, greater durability, reduced permeability, and faster heat penetration. Experimental archaeology has shown that chaff and other organic materials were used as clay temper for hand-built pottery in Latvia until the Middle-Late Iron Age ( $5^{\text {th }}-12^{\text {th }}$ centuries). There is also no doubt that the small plant pieces frequently seen in sherds could be traces of herbivore dung used as temper (Dumpe, Stivrins 2015). Horse dung was successfully used in reconstructing Narva culture tradition pottery with fine organic temper. The produced pottery was in fact light, strong, very sensitive for heating, and similar in appearance to Narva-type pottery at a sherd break (Mikšaite 2005). The use of herbivore dung in later pottery is not in doubt, but it is unlikely that hunters-fishers also gathered wild dung. Thus, if the use of herbivore dung is definitely proven in early Neolithic pottery, this would confirm a theory about keeping cattle earlier than the Late Neolithic. It is thought that waterfowl manure could have been used as temper and, it seems, in communities exploiting water resources this could have been easily collected (Tsetlin 2018, p. 213), but to prove this in Lithuania would require additional investigations.
Pottery with mineral temper appeared in SE Lithuania in the Middle Neolithic, i.e. the start of the $4^{\text {th }}$ millennium, and is connected with the classic Nemunas culture. The clay body was fairly evenly mixed, was well kneaded, and contained finemoderate sized (up to $2 \mathrm{~mm}$ ) ground granite temper as well as sparse organic temper (Fig. 2: 2-3). The bulk of the granite consisted of quartz minerals and therefore they are usually visible in sherd breaks, and in analysing thin-sections, feldspar, more rarely mica and amphibole minerals, can be seen. After achieving high temperatures by employing a mechanical effect, granite is fairly easy to crumble. It looks like these pottery producers must have been familiar with crushing, grinding, and sieving technologies, which could have also been used in food preparation.

The appearance of granite temper in pottery is connected with attempts to copy the structure and qualities of mountain silt or naturally mineral-rich clay, i.e. the first producers of pottery with mineral temper arrived from a mountainous location and adapted to the new location by recreating the clay body they needed by adding mineral tempers, which increase the fire resistance properties and allow a vessel to better withstand temperature fluctuations (Tsetlin 2018, p. 212).

Late Neolithic, so-called CWC, pottery is frequently distinguished by its grog, i.e. crushed ceramic temper. It is thought that grog is characteristic of only the CWC and allows this culture's corddecorated vessels to be distinguished from Post-CWC and GAC ware (Piličiauskas 2018, p. 122). However grog is also encountered in Dubičiai-type pottery (Tkachou 2018, p. 83), or in even older pottery from the Rakushechny Yar site (Dolbunova et al. 2020, p. 126). An increase in the use of grog is definitely observable c. 5000 BC in the pottery of N Hungary's Lengyel culture (Kreier et al. 2017) as well as in the Brześć Kujawski group of the TRB in the Polish Plain (Kukawka 2015). Thus, grog is not just a Corded Ware cultural phenomenon. 


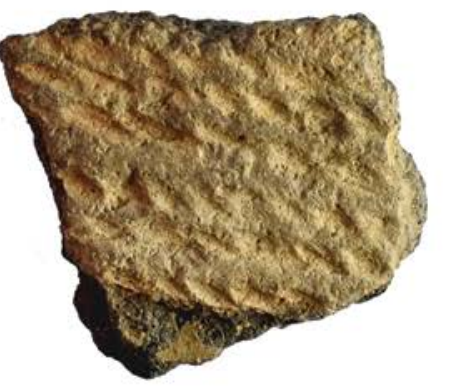

1.
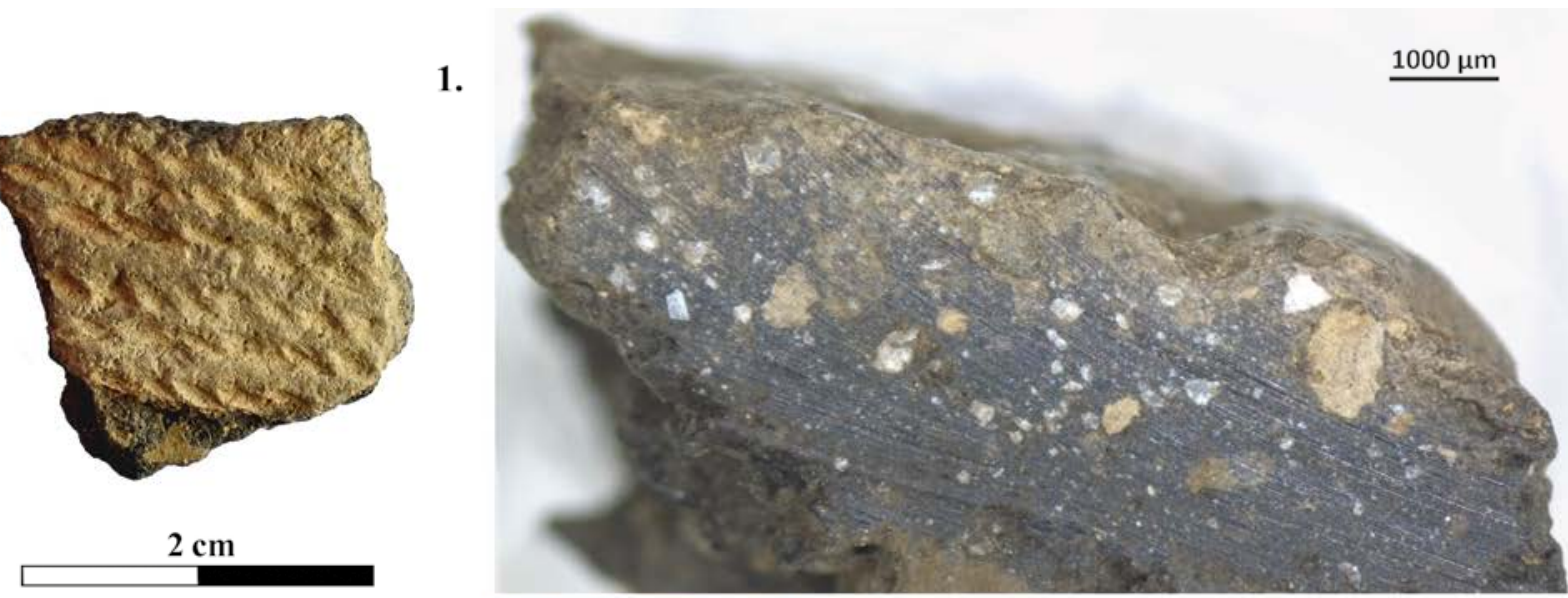

2.
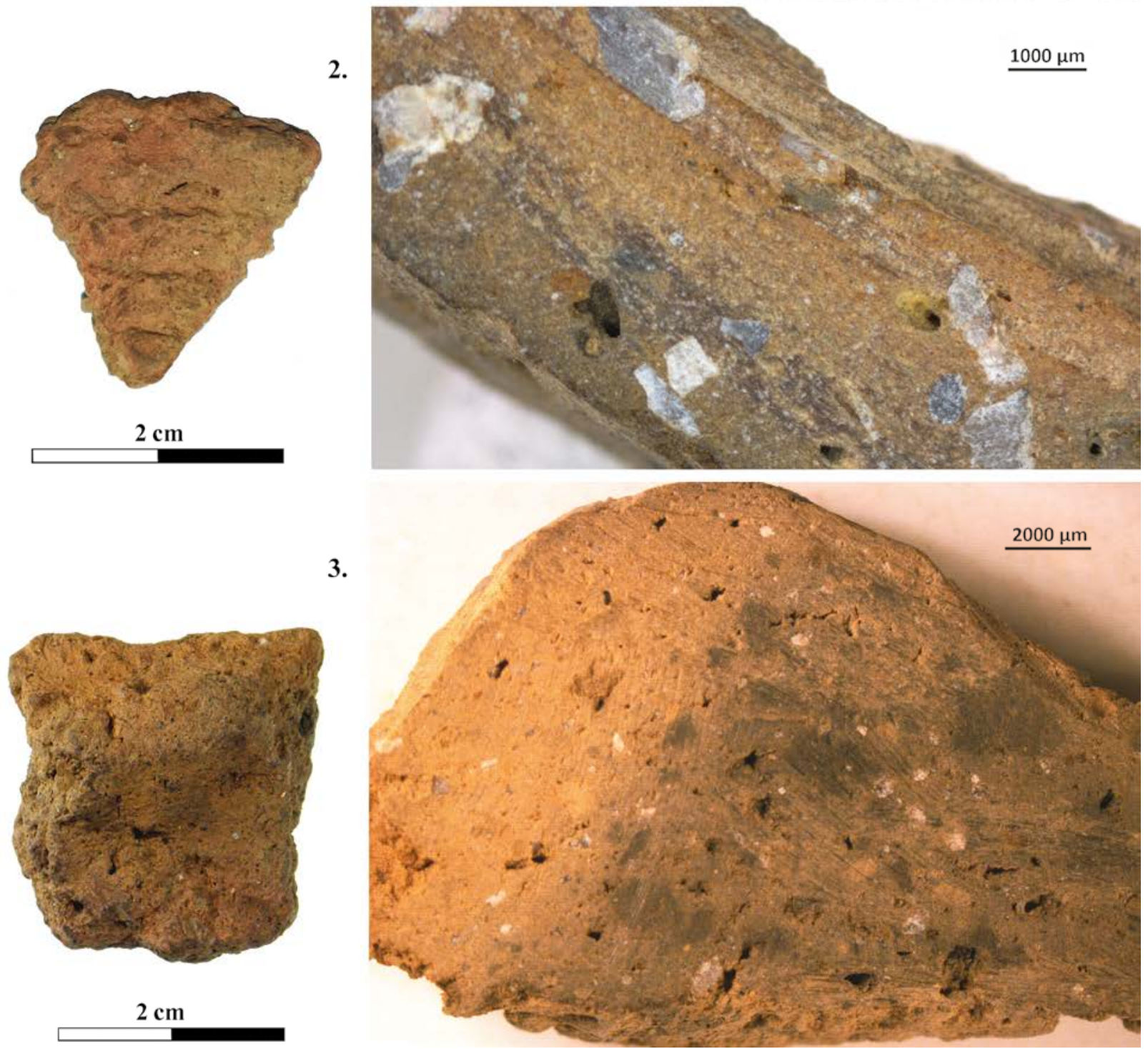

3.

Fig. 6. A diversity of grog visible in the cross-sections of sherds from the Margiai 1 settlement. Photos by E. Šatavičé. 
Grog is more often associated with ritual purposes than practical properties. It is thought that the experience of potters could have been symbolically handed down generation to generation or it was hoped that the strength of the old vessel would be conveyed to the new one. Yet another possible explanation is the artificial imitation of clay with natural temper. During the $11^{\text {th }}-9^{\text {th }}$ millennia BC, potters in the far east of Russia used a silt paste with natural inclusions of shale and ironstone, which looks like grog. Later pottery in this region was made from clay with grog, which may possibly be interpreted as a conscious imitation of the ancient tradition (Tsetlin 2018, p. 212-213).

Grog has been sought in SE Lithuanian pottery by comparing sherds with Corded Ware grog patterns from Estonia, Finland, and S Sweden. On the basis of geochemical data, Scandinavian scientists have determined that Corded Ware was spread by skilled female potters (possibly through exogamy) from the NE Baltic region to the $\mathrm{W}$ shore of Scandinavia. The clay paste of the analysed sherds greatly differs in respect to both chemical composition and morphology (Holmqvist et al. 2018). It appears that the interpretation of grog is much more diverse than has previously been stated (Piličiauskas 2018, p. 122). Even the particles of crushed old pots found in thin-section sherds can easily be confused with argillaceous grains or clay pellets, but it is possible to distinguish between them on the basis of certain features (Kreiter et al. 2017). It has also been observed that grog temper is also very similar to iron-rich deposits, which are very common in glacial clays (Larsson 2009, p. 137). Perhaps that is why in analysing Scandinavian Corded Ware, a grog group with an unusually large quantity of $\mathrm{FeO}$ was distinguished by its chemical composition (Holmqvist et al. 2018, p. 84, Table 3).

In analysing the cross-sections of SE Lithuanian sherds, particles similar to grog were noticed in only several sherds from the Margiai 1 settlement
(Fig. 6). One sherd looked like it was imported and was close to pottery, which has been fired in a reduced atmosphere and is characteristic of Scandinavian Corded Ware (Larsson 2009, p. 138), but its crosssection showed it to contain particles of light-coloured pottery, which were distributed very unevenly, were porous, had rounded corners, and were very fine (smaller than $0.5 \mathrm{~mm}$ in size) (Fig. 6: 1). This raises doubts as to whether ground particles of an old pot had been added intentionally. Other sherd crosssections displayed iron-rich inclusions, pellets, and perhaps charcoal particles. In examining the old sherd breaks, grog was seen to have perhaps also occurred in some of the sherds from the Lynežeris, Karaviškès, Gribaša, and Dubičiai settlements, but a determination with the naked eye during an analysis of old breaks of sherds is prone to many doubts. This does not mean that particles of old pots were not deliberately added, but it is important to properly evaluate this diverse component which is often called grog. Sand, which has always existed as an artificial or natural temper, should be especially accented in pottery ascribed to Corded Ware. In attempting to explain the variability of Corded Ware temper, it is worthwhile to remember the strong link noticed by Hodder between women, the home, the oven area, and the pottery ritual (Hodder 1990, p. 65). Perhaps in constructing pots beside a fire site, the clay body was simply tempered by picking up nearby sand. This could not only explain the small potsherd particles, but also the clay pellets, charcoal particles, and organic tempers discovered together with sand in the clay body.

\section{Coiling}

The size, shape, construction method, and temper of a hand built vessel reflect the community's traditions, while the construction process is connected with the qualities of the individual potter, such as professionalism, thoroughness, and dexterity. Pots were built from clay coils or strips, beginning 


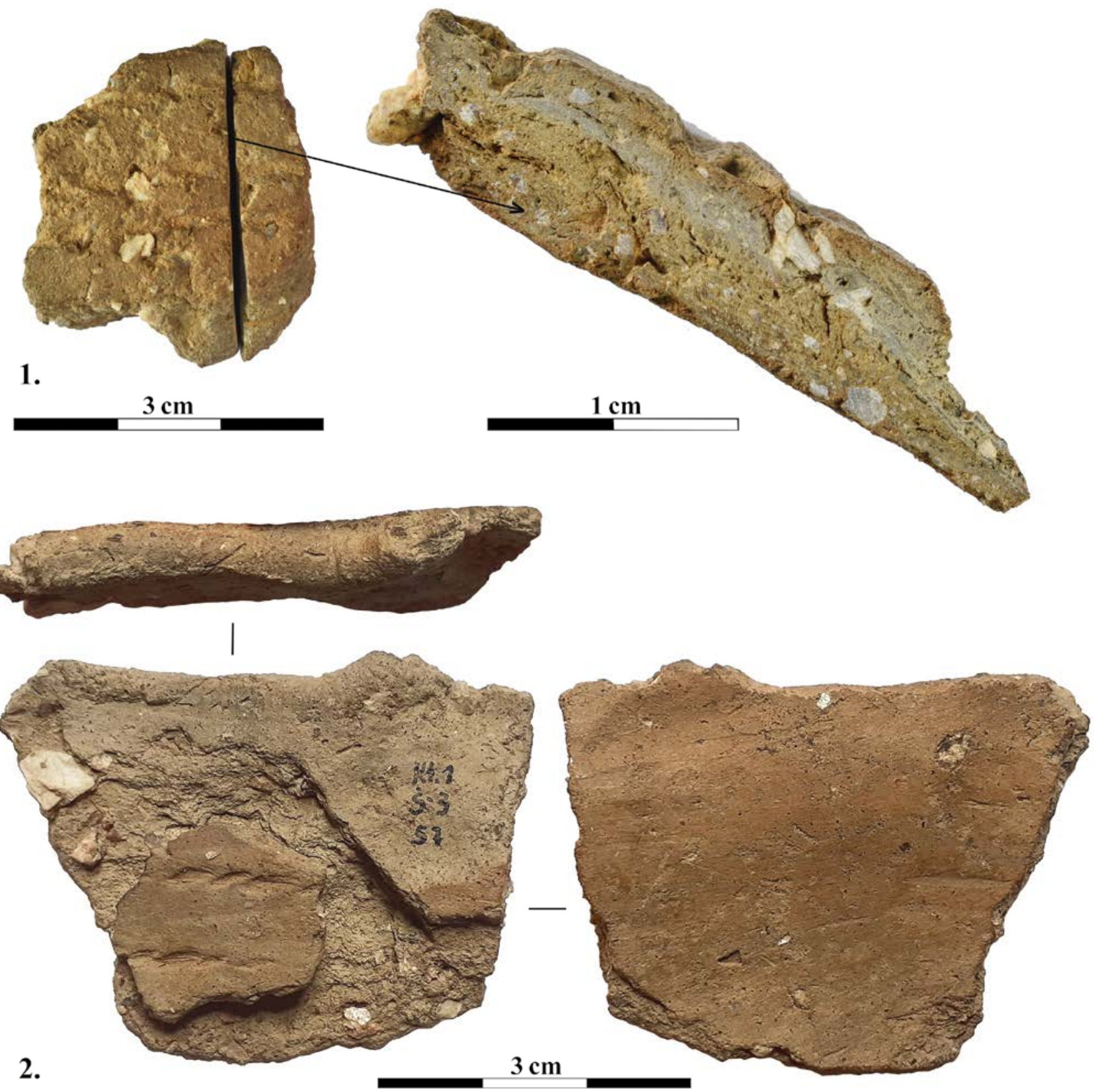

Fig. 7. Examples of coil joints: $1-\mathrm{Z}$ and $\mathrm{U}$ joints visible on a sherd cross-section (Margiai 1 settlement); 2 - a poorly smoothed $\mathrm{N}$ joint on a sherd from the Katra 1 settlement. Photos by E. Šatavičé.

at the bottom and building the vessel to the top. Based on the coil structure, pottery is assigned to types: U, N (Kriiska 1996, p. 380) or even Z and n (Piličiauskas 2018, p. 123). U joints are considered to be characteristic of hunter-gatherer communities. In contrast to the $\mathrm{U}$-type, $\mathrm{n}$ and $\mathrm{Z}$ joints are considered more characteristic of the GAC, $\mathrm{N}$ joints the CWC (Piličiauskas 2018, p. 123). It must be noted that the coil assembly method is more connected with the shape of a hand built vessel than with the cultural coiling traditions. The earliest pots had pointed bottoms and walls that usually rose in a fairly straight 
line to the top. The Middle-Late Neolithic Nemunas culture pots, which had both pointed and flat bottoms, are already somewhat curved with slightly bulging sides while in the Late Neolithic the sides of both GAC and other pots were fairly clearly bulging and also flared out at the top to end in an S-shaped rim. It is unlikely that an effort was deliberately made in any period to create grooves or thin the edges of the coils; vessels were probably built from coils with uniform, somewhat narrowing edges. Using the fingers to evenly draw the surface of the lower coil upwards both inside and outside the pot resulted in a U-shaped joint and a smooth vessel wall. By drawing the lower coil upwards on the inside and upper coil downwards on the outside, the vessel wall bends outward, the vessel becomes wider, and an $\mathrm{N}$-shaped joint is created. The reverse, a Z-shaped joint, created by drawing the lower coil upwards on the outside and the upper coil downwards on the inside, results in the vessel becoming narrower, completing the bulge shape (Fig. 7: 1). To make the vessel walls thicker, the inner and outer surfaces of the upper coil are drawn downwards, thereby creating an n-shaped joint. Thus, a cord-decorated sherd, which broke along a poorly smoothed $\mathrm{N}$ joint, clearly shows it is made of coils with rounded edges (Fig. 7: 2). Although an attempt has been made to associate the quality of the smoothing at the coil joint site with cultural traditions, i.e. by noting that Corded Ware joint sites are invisible (Piličiauskas 2018, p. 123), nevertheless vessel construction quality and thoroughness are more connected with the potter's personal qualities.

In reviewing SE Lithuanian pottery, quasi copies of the same vessels are frequently noted; some of the sherds of a very similar style seem to have been wellmade, while others seem to be an effort to learn by mimicking professional results. This has prompted a hypothesis that the children of Stone Age communities learned to build pots by mimicking the adults. The creation of pots by children was thoroughly analysed in the $13^{\text {th }}-18^{\text {th }}$-century material from Vilnius Lower
Castle by conducting dermatoglyphic research on fingerprints that have survived on the pottery. Based on the breadth of the papillary lines, it was determined that children had begun at the age of 8-12 years to make pots (Blaževičius 2019). A search made for fingerprints on SE Lithuanian Stone Age pottery for another such analysis mostly revealed only fingerprints without papillary lines, which yield statistically unreliable results. Only one clear child print with an epidermal ridge breadth of $0.391 \mathrm{~mm}$ was discovered on a sherd, which came from the Katra 1 settlement. Based on the applicable age calculation formula (Králík, Novotný 2003), it was made by a 12.3-year-old child. It would seem that this sherd belongs to the same Katra 1 cord-decorated pot with the unsuccessfully smoothed $\mathrm{N}$ joint and may illustrate the process of learning to make pottery.

An attempt to evaluate fingerprints without using paleo dermatoglyphics was made by creating experimental clay tiles with the fingerprints of 6,9 , and 12 -year-old children. In analysing the fingerprint marks on Late Neolithic pottery, prints somewhat larger than those of a 12-year-old child are mostly encountered and could be connected with teenagers or women.

In analysing the pottery from the Middle Neolithic Nemunas culture, extremely large fingerprints uncharacteristic of those on other pottery were immediately noticed. The paleo dermatoglyphic pattern discovered on the rim of the very skilfully made vessel from the Šakiai settlement confirmed these observations. An epidermal ridge breadth of $0.492 \mathrm{~mm}$ is definitely ascribable to an adult male (Králík, Novotný 2003) (Fig. 8). That the print unquestionably belongs to an adult male was also confirmed by another method, the measurement of fingerprint ridge density (Sanders 2015), where 11 finger ridges were counted in a $5 \times 5 \mathrm{~mm}$ square.

The Nemunas culture pottery made by adult males not only refutes the established stereotype that only women were involved in the production of 


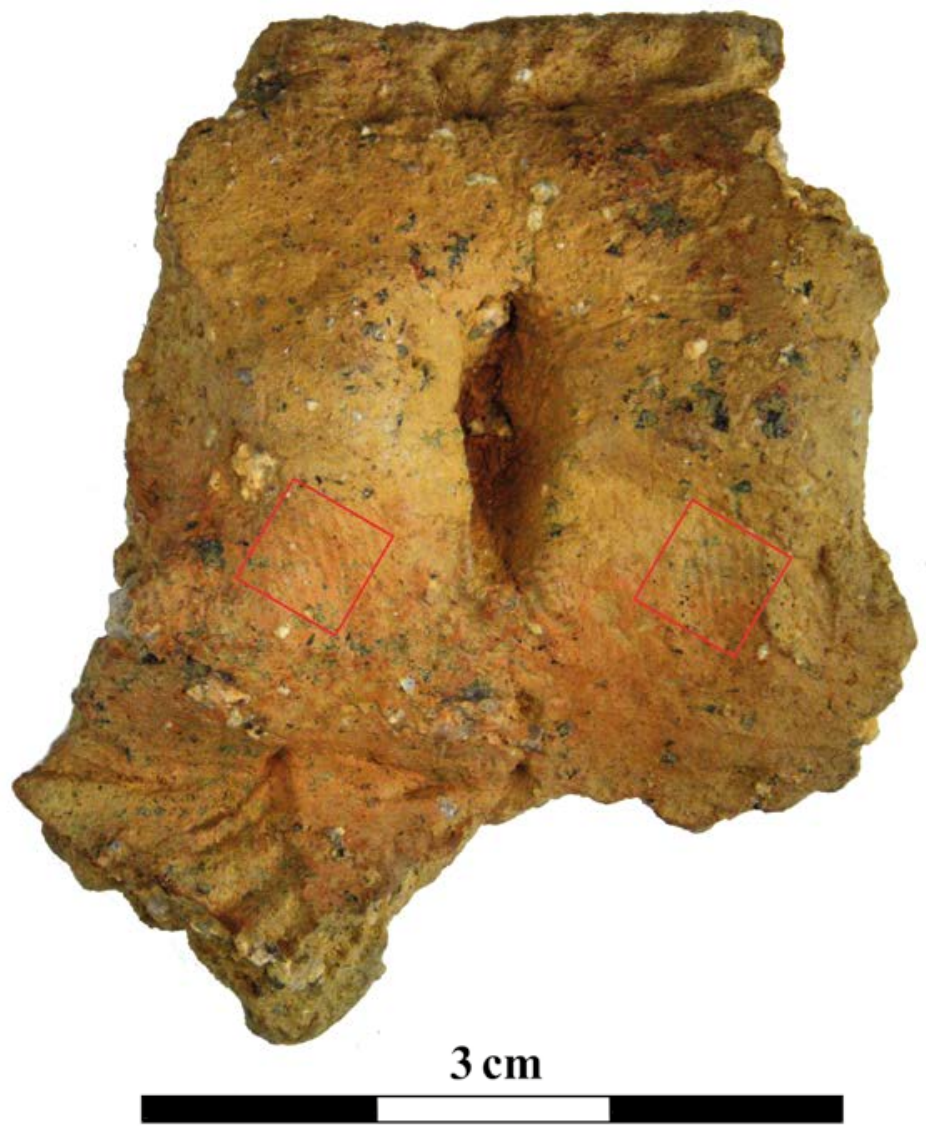

Fig. 8. An adult male fingerprint seen on the rim of a Nemunas culture pot from the Šakès settlement. Photo by E. Šatavičé.

pots, but also reflects a new, much more advanced stage of pottery development, which was perhaps connected with a specialisation of travelling potters. It is likely due to a demand for high quality vessels that such professional potters possessed special status in the society. Thus, in the presence of even a small number of high status newcomers producing pottery that the indigenous people were trying to copy, the community's habitus could have changed and, even without a large influx of foreigners, a new genetic infusion could have begun to spread quickly along patrilineal lines.

\section{Decoration}

Vessel decoration is perhaps the main feature allowing individual vessels to be ascribed one or another cultural group. But, in fact, the personal artistic expression of a separate individual often exists alongside the community's traditions. Vessel decoration begins with the preparation of its surface. From the earliest times the surface, both inside and out, of the majority of the vessels was smoothed with a handful of grass or a comb tool, both of which left lines. In SE Lithuania, this is frequently the only wall decoration, which is sometimes supplemented by a line of ordinary impressions around the rim.

It is possible to divide the impression designs into three groups based on their complexity:

1. One or several separate rows of simple repeating impressions;

2. Impressions that form a composition or were made by a purpose-made tool (double or multi-toothed stamps or a cord wrapped on stick or cord core);

3.3-D ornaments created with a tool that was pressed into the clay at varying angles and to varying depths.

Impressions ascribable to the first group are frequently encountered in pottery from various periods. They do not require a great deal of time or imagination, and the tool that was used allows one to easily guess the future image on the pot's wall. A row of deep pits around the rim, which is frequently the pot's only decoration, predominated in SE Lithuania up until the Bronze Age.

Impressions of small orderly or irregular pits, which are not always traces of a sharpened stick, are frequently encountered. Impressions of Panicum miliaceum have been noted on the bottom of a pot from the Bronze Age Narkūnai hillfort, Triticum sp. or Hordeum vulgare on the pot's walls (Podenas 


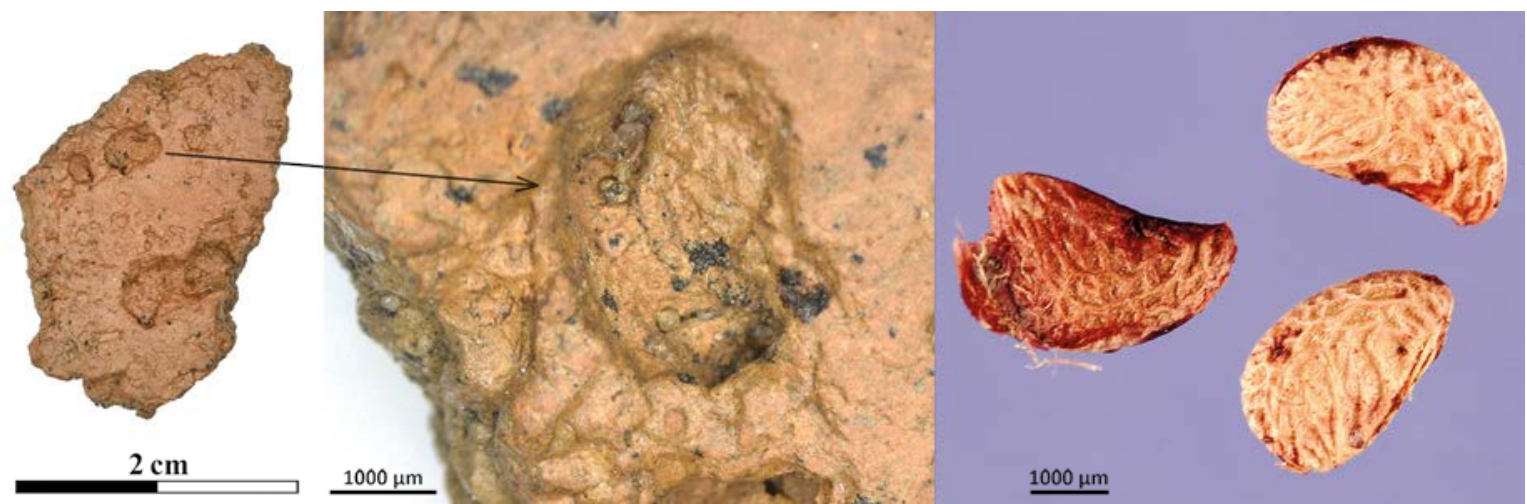

Fig. 9. Impressions reminiscent of dewberry (Rubus caesius L.) seeds on a sherd surface from the Barzdis Forest settlement and such seeds. From <http://climbers.lsa.umich.edu/?p=1063> [Accessed 5 May 2020] and photos by E. Šatavičé.

et al. 2016, p. 214). Impressions of these domesticated plants have also been noticed on Late Neolithic pottery from the Stary'e Jurkovichy 1 and Kamen 6 settlements in Belarus (Грикпедис et al. 2018). It is often thought that the seeds and other parts of domesticated or wild plants found their way onto the walls of pots accidentally, but this could have also been deliberate vessel decoration (perhaps by children). The exterior of a pot from the Barzdis Forest settlement was decorated with unevenly arranged, irregularly oval impressions. In analysing them with a stereo-microscope, the rough surface characteristic of seeds was noticed, and after comparing the size and shape of these impressions with the seeds of Rubus caesius L., they appeared, in fact, to be very similar (Fig. 9). The round dewberries could have looked good imbedded in the wall until the pottery was fired, but perhaps the frequent inclusion of plants, especially domesticated ones, in various Neolithic culture pottery had a deeper, ritual meaning.

Cord impressions should also be ascribed to the first, more ordinarily decorated group because various cords were often needed in the home so that there was no need for additional preparation to make the design. In educational jobs a cord is the usual device selected by children for decoration due to its speed, ease of use, and beautiful design. In analysing sherds with cord impressions, an attempt was made to understand whether the characteristics of the cord's braid and material reflect cultural-chronological tendencies. The double cone clay spindles that are ascribable to the Late Neolithic and were discovered at the Karaviškès 6 and Katros Ištakos 1 settlements in SE Lithuania (Piličiauskas 2018, p. 88) show that thread spinning already existed in the Neolithic, probably using sheep wool. Although it is likely that wool yarns were already being used at that time, they were unsuitable for decorating pots because they were too soft to leave a visible cord impression. Impressions of roughly $2 \mathrm{~mm}$ wide cords twisted at a $40-45^{\circ}$ angle with 7-8 twists per $2 \mathrm{~cm}$ are usually discovered on SE Lithuanian pots (description method after Grömer, Kern 2010). Experimental archaeology shows that the cords used for the impressions were usually about $2 \mathrm{~mm}$ wide and braided from grass or bast fibre. Less common impressions made by extremely fine (roughly 1-1.2 mm wide) cords were found on small beackers from the Gribaša 4, Karaviškès 6 (Piličiauskas 2018, p. 79, Fig. 42:1; p. 82, Fig. 44:8), also Margiai 1, Šakès settlements. Such cord could have been made of flax, but since this plant had not yet reached Lithuanian territory, it is more likely that supple lime bast was used (Grömer, Kern 2010, p. 3142).

Both SE Lithuania and Europe often exhibit a diversity of cord impressions, some of the cords having been braided very elegantly and impressed 


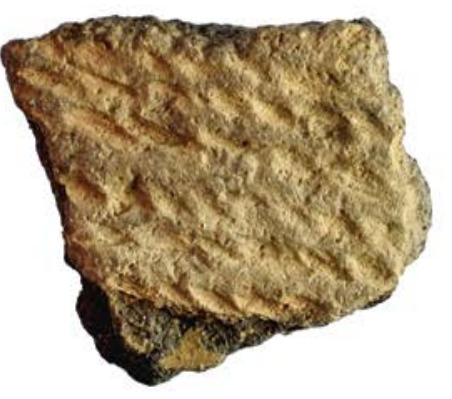

1.
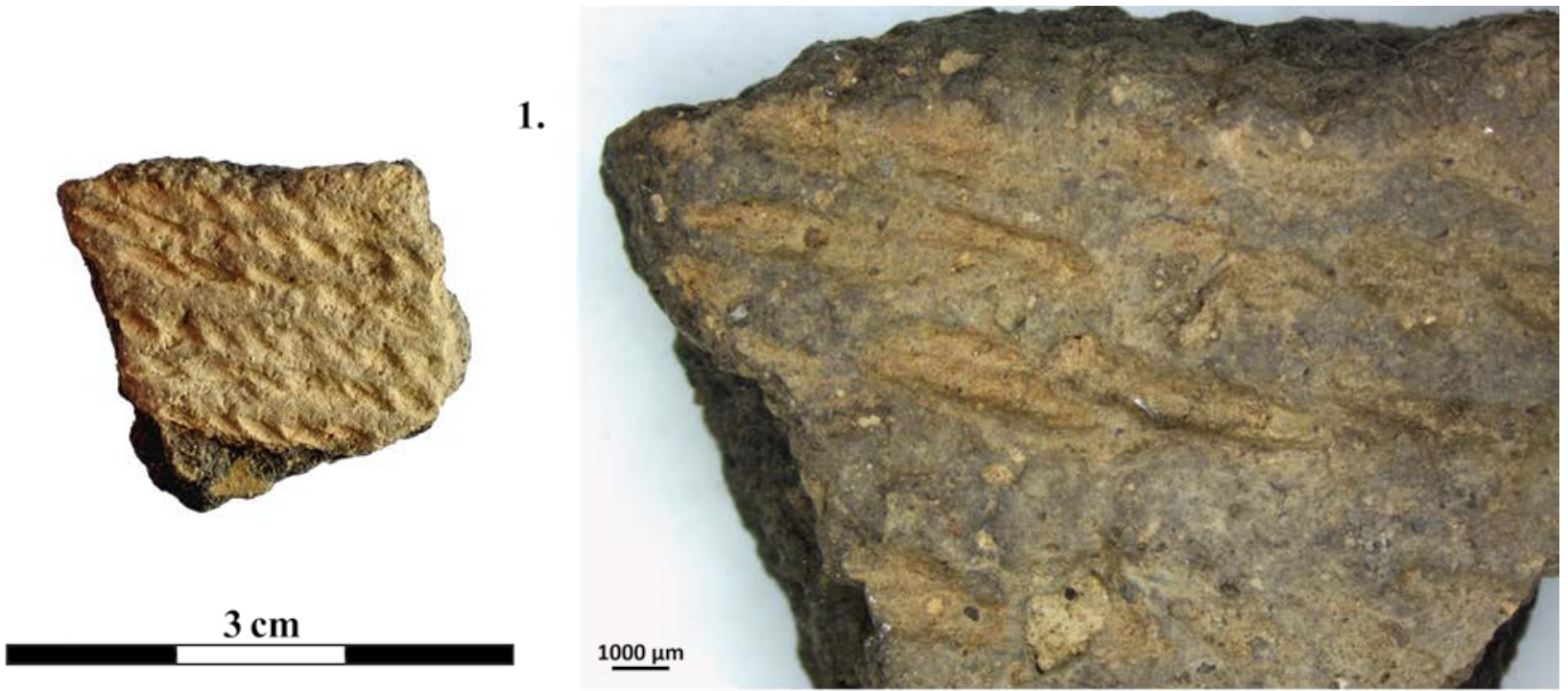

2.

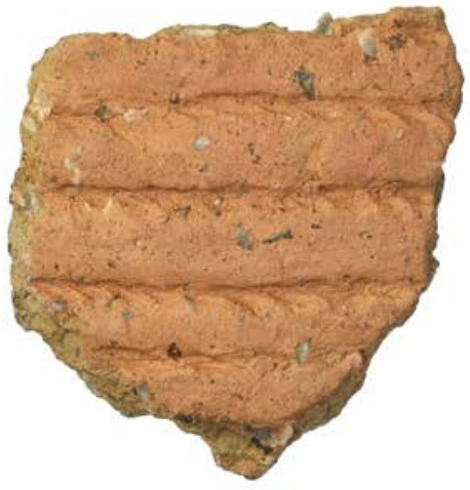

$3 \mathrm{~cm}$

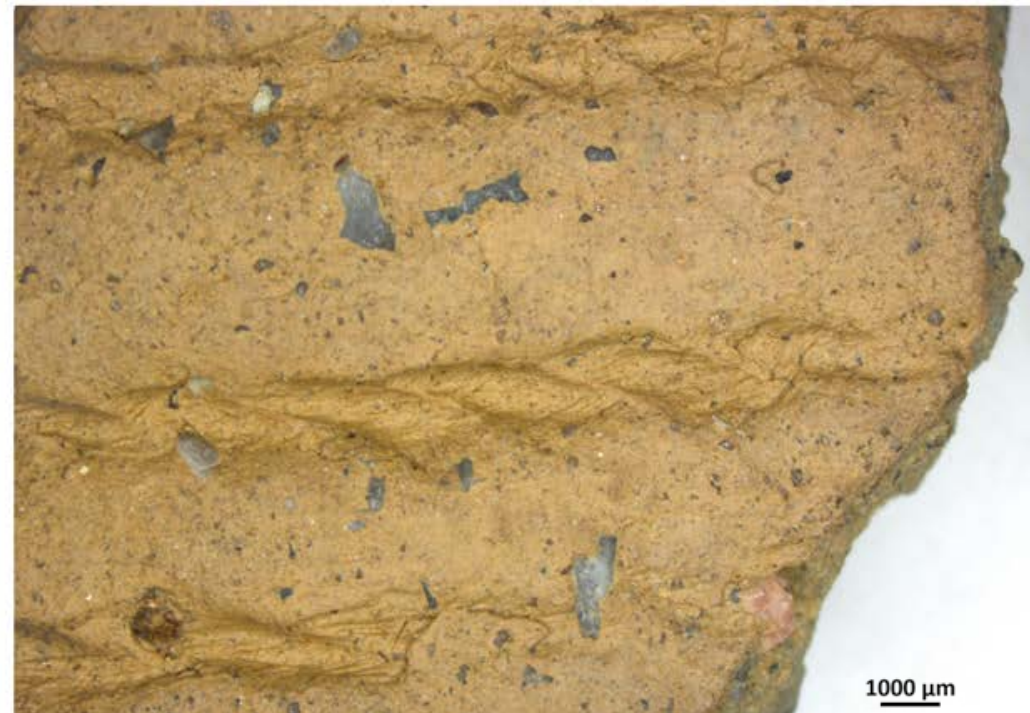

Fig. 10. Cord impressions on the surfaces of sherds from: 1 - Margiai 1; 2 - Šakès. Photos by E. Šatavičée.

at an even depth so that the structure of the cord's strands are clearly visible, but the greater part of the vessels have traces of cords that were carelessly and unevenly braided and hurriedly pressed into a poorly smoothed surface. Perhaps the biggest diversity of the different cords impressed to a especially nonuniform depth is seen on the classic CWC sherds from the Margiai 1 settlement (Fig. 10: 1). The cord impressions overlap irregularly; although all of the cords are about $2 \mathrm{~mm}$ wide, some of them are braided more densely, at about a $50^{\circ}$ angle, yielding even
10 twists per $2 \mathrm{~cm}$, and some are especially loose, braided at about a $20^{\circ}$ angle yielding just 5 twists per $2 \mathrm{~cm}$. Such impression diversity is usually explained as the difference between the work of a 'master' and an 'apprentice' (Grömer, Kern 2010, p. 3144), but it could also reflect chronological differences. It should be noted that overlapping impressions of different sized cords are more characteristic of SE Lithuanian pottery, which is very likely to contain grog. It would seem that cord impressions there had a more ritual significance, as if an attempt were being made to 
bind or protect the vessel's contents. Meanwhile evenly deep impressions of neat, hard-twisted cords, which are more associated with an aesthetic function, are more characteristic of the very Late Neolithic (Fig. 10: 2). It should be noted that the absolute majority of all of the various cord-decorated pottery have Z-plied impressions, which were left by S-plied cords. The cord ply direction should be associated human biological qualities rather than cultural or chronological differences. For a right-handed person, $S$-plied cords are more comfortable, to a left-handed person, Z-plied (Grömer, Kern 2010, p. 3144). S-plied impressions, which are characteristic of a left-handed potter, have been observed in SE Lithuania on only few sherds: from the Margiai 1, Katra 1 (Fig. 7: 2), Katra 4 (one each), and Dubičiai 1 (Salaitè) (two rim sherds) settlements. None of the pots was attractive, all had been manufactured fairly coarsely with coarse mineral temper, and all had impressions left by a thick cord of varying braid density. Pot construction is first of all an individual task and therefore it is difficult to understand theories that local huntergather women could have been kidnapped by CWC communities and forced to produce coil vessels in accordance with CWC rules (Piličiauskas 2018, p. 147). Although this pottery does not belong to the CWC, such examples of coarse, carelessly coil pottery could perhaps confirm such an hypothesis.

In analysing the development and complexity of decoration it is important to note that the idea of decorating with a cord appeared in the SE Baltic region already in the $5^{\text {th }}$ millennium $\mathrm{BC}$; those motifs are, in fact, more complex, and should be ascribed to the second group on the basis of how they were made. Impressions, which were made by string wound on a cord or a stick as well as by knots and which were arranged in compositions that densely covered a vessel's entire surface, are characteristic of the traditions of not only the Narva, but also the CWC, which was further north (Akulov 2019). Various imprints of thin string wrapped around a narrow stick are especially characteristic of Middle Neolithic pottery in E and W Lithuania (Iršènas, Butrimas 2000). Isolated wrapped stick impressions, which reflect influences from the north, are also found in SE Lithuania (Марцинкевичюте 2010).

For a long time, the use of a comb stamp for decorating was ascribed to the Comb Ware throughout the E Baltic region. After recalling a globalisation theory that explains the spread of pottery ideas (Hommel 2018) and the existence of Far Eastern sources for the pottery in the entire E Baltic region (Jordan et al. 2016), it is possible to actually notice general tendencies. The decoration of the earliest Dubičiai-type pottery in SE Lithuania shares a similarity with that of the Narva cultural to the N, but clear differences with Comb Ware according to a statistical correspondence analysis (Piezonka 2015). Already in the $2^{\text {nd }}$ half of the $20^{\text {th }}$ century, Rimantiene had actually noticed that the comb stamp and other decoration on SE Lithuanian pottery had been acquired not from the N, but from the Dnieper-Don culture to the SE (Rimantienè 1984, p. 125). Imprints made by a thin and slightly curved fine-toothed comb have frequently been encountered in W Belarus, but they are uncommon in Lithuania. SE Lithuania was only the NW periphery of the Pripyat-Neman Culture, which was widespread in the Nemunas river basin, Belarus, and N Ukraine and belonged to the large cultural sphere of the Dnieper-Don culture, which included the Dubičiai and Sokołówek pottery types and the Volhynia culture (Tkashou 2018). The fairly broad diversity of all the pottery characteristic of this cultural tradition probably reflects both chronological and territorial differences as well as manifestations of the agency of separate communities.

While similar pottery motifs characteristic of hunters-fishers-gatherers were used in the pottery of the Early Neolithic communities, pottery became a distinct representative element of different communities in the Middle Neolithic. The new Nemunas culture, which was not connected with 


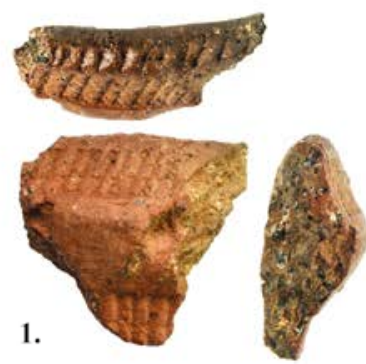

2.

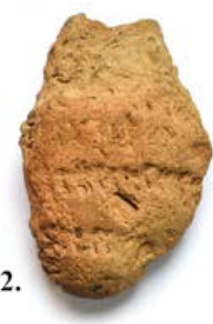

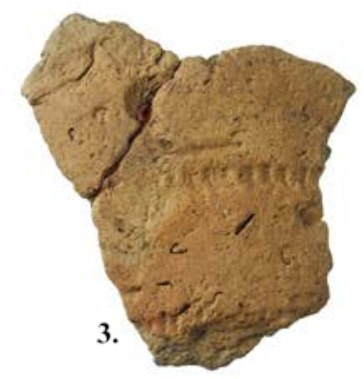

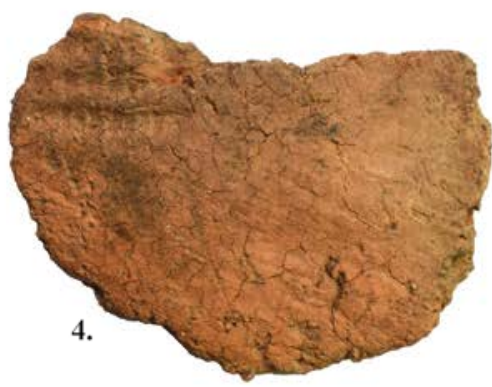

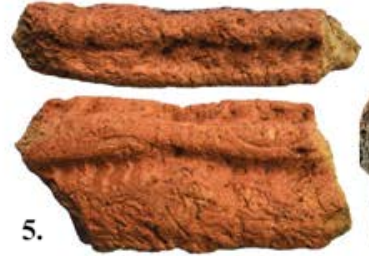

8.

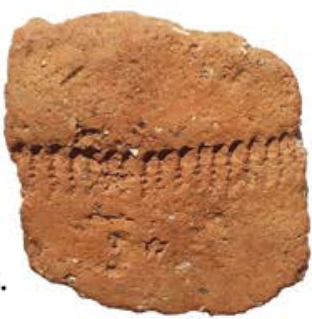

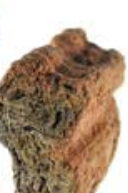

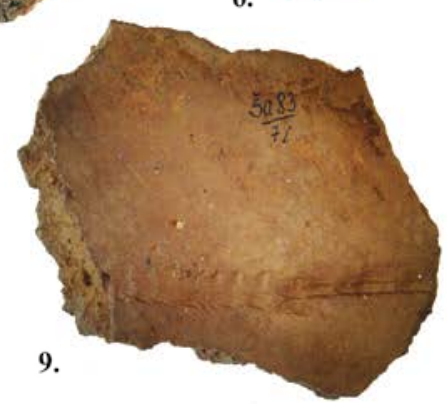

6.
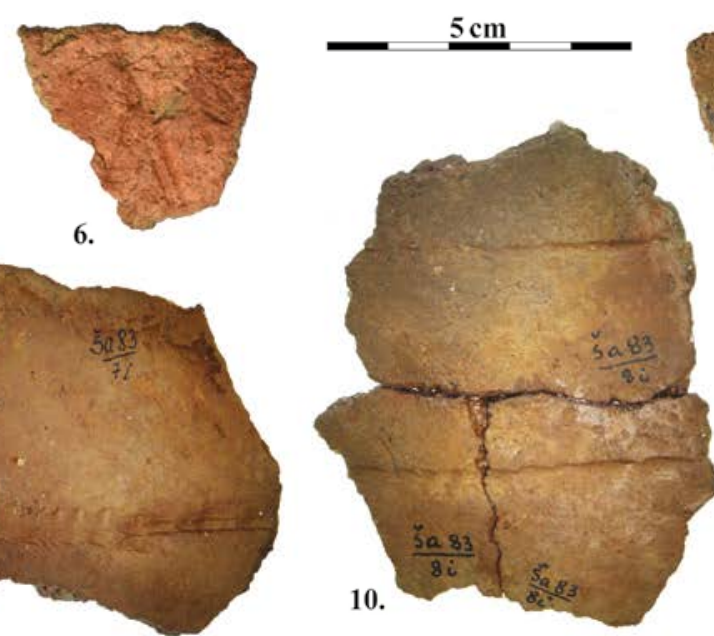

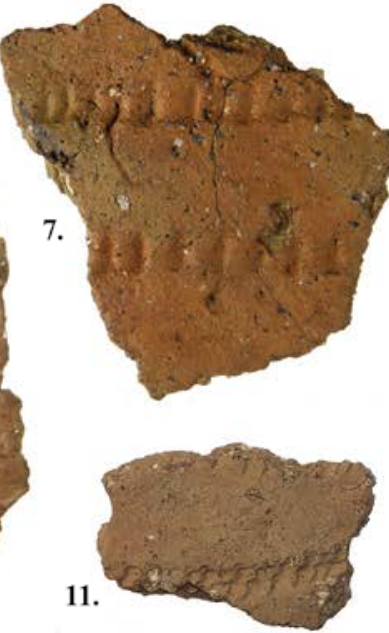

Fig. 11. A 'Cascading band’ decorations from: 1-7 - Margiai 1; 8 - Karaviškès 6; 9-11 - Šakès. Photos by E. Šatavičè.

the Early Neolithic traditions or the Dnieper-Don cultural sphere, is often distinguished on the basis of its original pottery decoration (Czarniavskij 2001). Although the composition of the pottery's clay body changed (from plant to mineral temper), it is possible to find similarities with Dubičiai-type pottery.

The pottery of the Nemunas culture is characterised by complex decorative designs requiring skill. One of the most characteristic elements is a 'cascading band', as it is known in Lithuanian, i.e. a dense row of impressions, which were usually made on an especially smooth surface (Fig. 11). It was previously thought that this smoothness was obtained through a coating of slip, a fat clay (Rimantienè 1984, p. 121), but experimental archaeology has shown that in polishing the surface with a stone, the ground granite particles of temper move inside the vessel's walls, so the surface can be polished to sheen (orally reported by Dainius Stazdas). A 'cascading band' is created by densely placing impressions without completely lifting the slanted tool from the surface between impressions. Not only were most of the examples of this design discovered at the Margiai 1 and Šakès settlements, but the teaching process that occurred at the site was also noted. Sometimes spaces of varying sizes were left between the impressions (Fig. 11: 7), other times an unbroken groove of impressed lines quickly made in a casual manner is visible on a well smoothed surface (Fig. 11: 9, 10).

Although a 'cascading band' is considered a feature of the Nemunas culture, it is possible to already see similar elements in Dubičiai-type pottery. For example, a fairly awkwardly decorated pot with plant temper was found at the Margiai 1 settlement (Fig. 11: 5). 


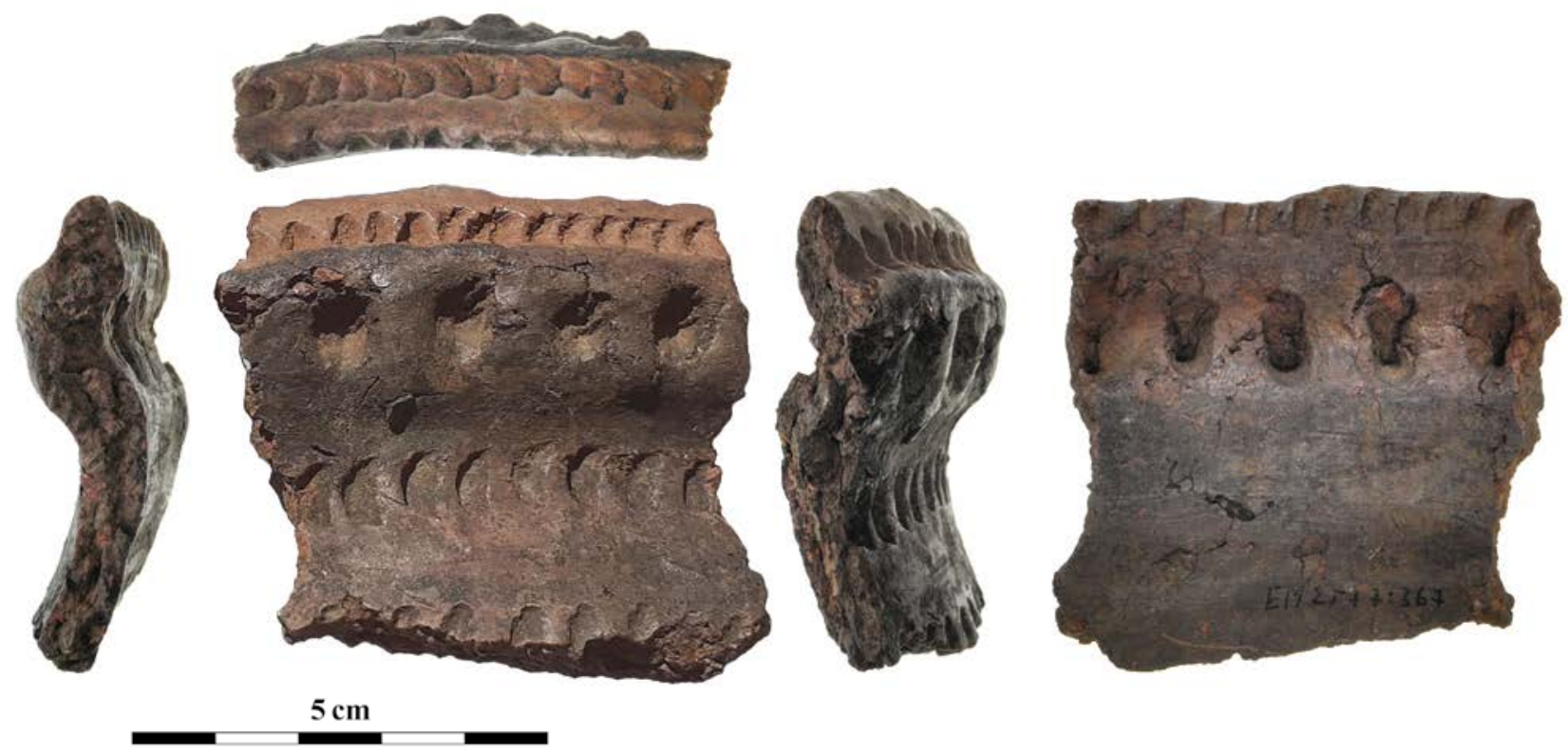

Fig. 12. The rim of a Nemunas culture pot from the Kabeliai 23 settlement. Photo by E. Šatavičé.

The most impressive thing are the Nemunas culture rims which are not characteristic of the neighbouring lands and have a shape created by impressing very deep pits (without piercing the rim) from inside and out. Frequently several rows of decorative elements, impressed to different depths, are found on the inside and outside of the rim of the same vessel; in such a manner a lip or curve can be shaped by a 'cascading band'. The design transcends the 2-D boundaries and becomes 3-D (Fig. 12).

In photographing or examining the designs of Nemunas culture pottery in a different light, they change markedly, like holograms, which should be especially so in the light of a flickering fire. It is likely that the communities deliberately made these designs in order to obtain such an effect, which not only clearly distinguished them from the others but was perhaps even a ritual element.

It should be noted that pottery with the complex designs characteristic of the classic Nemunas culture is fairly rare in Lithuania, compared to NE Poland or Belarus, as fewer than 30 vessels have been found. Could the small number of impressive pots be explained by the agency of only a few male individuals? That could in part be true since an attempt was made to copy them but simpler decoration traditions were selected by the Nemunas culture in Lithuania. It is likely that various pottery production traditions converged in SE Lithuania during the $4^{\text {th }}-3^{\text {rd }}$ millennia BC. These same settlements saw the discovery of vessels with designs reminiscent of the Narva culture traditions found to the $\mathrm{N}$, a shape and clay body reminiscent of the Nemunas culture to the $S$, and perhaps also of the TRB traditions. In addition, the discovered GAC and CWC pottery, based on its style elements in Lithuania, is also frequently reminiscent of the traditions of the same Nemunas culture.

In analysing the pottery according to the complexity of its decoration, a regression is seen in Late Neolithic CWC pottery in comparison with the pottery of the so-called Subneolithic cultures. It seems that in the Late Neolithic, pottery lost its meaning as the main representational symbol, but at the very beginning of the Bronze Age a renaissance of ceramic decoration is once again noticeable. In SE Lithuania, 


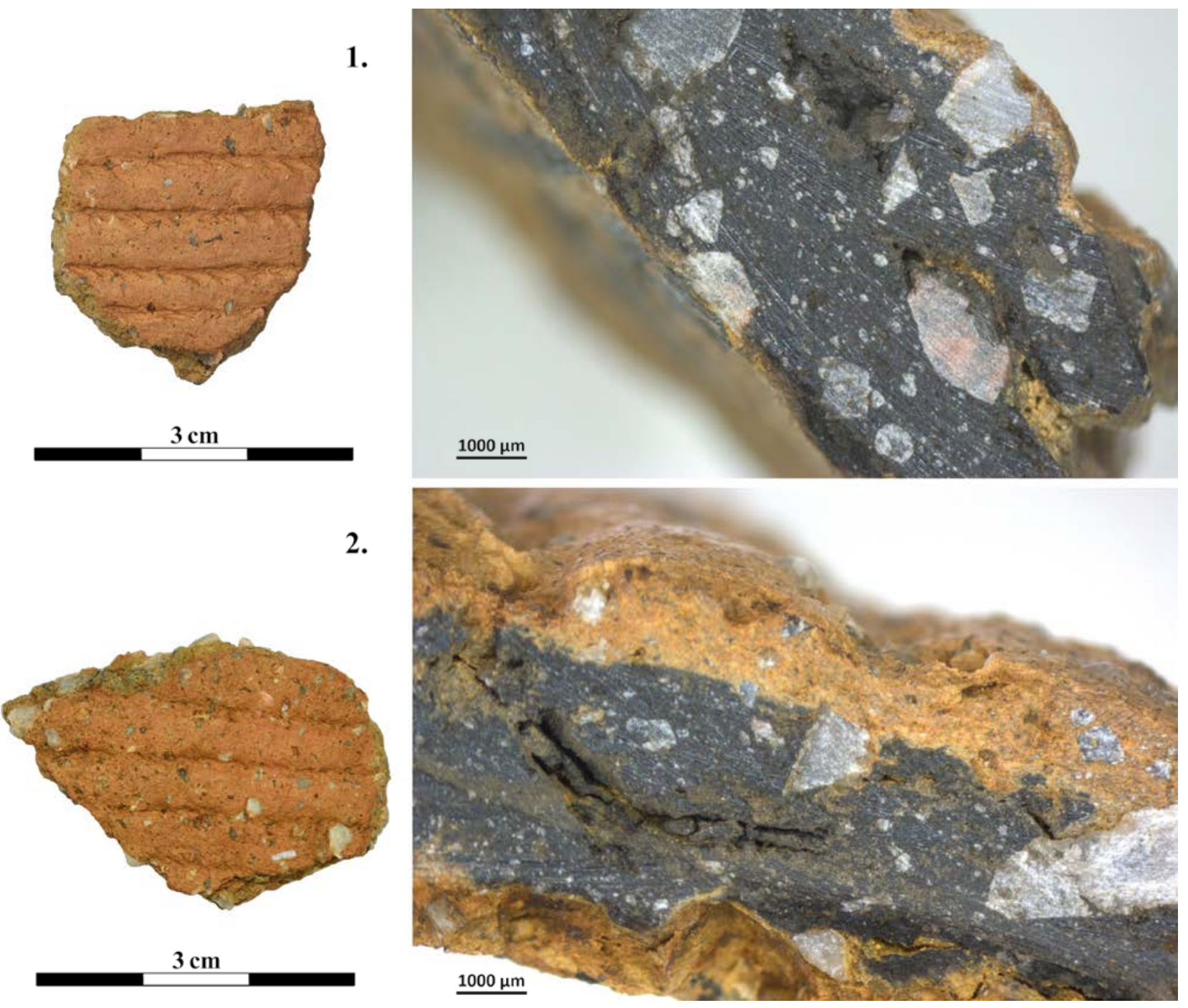

Fig. 13. Sherds of vessels fired in a reduction atmosphere from Šakès settlement. Photos by E. Šatavičè.

pottery decoration motifs continuing the Nemunas and Narva culture traditions, supplemented by elements characteristic of the CWC or GAC, appear once again.

\section{Firing}

The majority of the Stone Age vessels in SE Lithuania were fired in an uncontrolled oxidation atmosphere, at a fairly low temperature of up to $600{ }^{\circ} \mathrm{C}$. Pottery with organic temper required slow firing at a low temperature. Although it is asserted that ground stone temper increases heat and air penetration within the fabric, all of the vessels were evenly fired (Dumpe, Svirns 2015). But the crosssections of the analysed sherds, despite the abundant mineral additives, display traces of reduction in the centre of the walls. This is perhaps connected with the carbonisation of organic matter.

Firing in a reduced atmosphere is considered one of the main criteria for Corded Ware (Larsson 2009). According to these criteria only a few vessels from Dubičiai 1 and Margiai settlements (Piličiauskas 2018, p. 73, Fig. 38: 2; p. 93, Fig. 54: 1, 2) can really be ascribed to the CWC. Initially it seemed that only 
one of the sherds with an analysed cross-section had been fired in a closed reduction atmosphere (Fig. 6: 1), but it was noted that at least one of the cord-decorated sherds from Šakès, despite a light coloured surface and abundant ground stone temper, displayed clear traces of reduction throughout the sherd's cross-section (Fig. 13: 1). According to Larsson, this is characteristic of the earliest attempts at firing in a reduction atmosphere, when a vessel, after being fired in a reduction atmosphere, is taken out while still hot and left to cool in the open air. Oxidisation quickly occurs during this cooling and the vessel's surface becomes light coloured. A sharp transition to reduced clay is visible immediately below the surface in the cross-section (Larsson 2009, p. 245). Thus, although the Šakès settlement was not included in the CWC list (Piličiauskas 2018), some cord-decorated sherds from this site are more characteristic of the CWC than many from other sites in SE Lithuania.

\section{POTTERY USE}

Sherds with various clay bodies, surface treatments, and decoration have been found in SE Lithuania. Unfortunately, they are often so small and eroded that it is difficult to say whether they belonged to the same pot, and the discovery of exceptional individual sherds raises doubts as to whether the entire vessel had ever really been in that settlement. This sherd isolation is perhaps a consequence of the intense spatial movement of artefacts that occurs when people and animals walk in the sand and when Stone Age people cleaned the settlement's territory. But sometimes an impression is formed that not only unusual new pots could have reached the communities through the trading of the pots' contents, but also inhabitants could have simply brought home prettier distinctive sherds. The bulk of the pottery consists of pots without any cookedon food residue or other signs of the vessel's use.
This is mostly the result of the poor conditions for the survival of organic material, but the abundant, carefully made, and complex decoration of some vessels allows one to speculate that the pots were used not only for food production but as centrepieces.

A vessel's purpose is shown by its size, but it is difficult to calculate this due to the smallness of the sherds and the flattening of larger sherds that were poorly fired. No large (over 50 litre capacity), stationary vessels intended for long-term storage have been found in SE Lithuania. The majority of the Early-Middle Neolithic vessels are fairly small (roughly 5-8 litre capacity), mobile pots. This size must have been convenient for the daily food needs of one family. Despite their unique design, Nemunas culture pots maintained a similar size compared to Dubičiai-type vessels.

The majority of the widely investigated Stone Age settlements have seen the discovery of roughly 0.5 litre capacity and smaller, thin-walled, pointedbottom cups and bowls, which are decorated with various designs, but it is difficult to determine their chronology and purpose. These were perhaps the first individual vessels and their shape and size were adopted by copying those of the Narva culture communities.

In the Late Neolithic, the appearance of amphora, beakers, and various-shaped pots is seen and should be connected with GAC and CWC influence. Such vessel differentiation not only reflects an augmented diet with more diverse food, but also demonstrates an altered perception of individual property and a need to have personal vessels.

In analysing a settlement's pottery, it is important to perceive its connection with food. Food can not only be kept or cooked in vessels, but also tasted, given away and sacrificed. The taste of food can influence choices to use milk or to begin to grow grain for porridge. It is unlikely that pots without any content could be a symbol of social status. It is often thought that the first owners of pottery ate 
bland food and did not think about its taste, but a phytolith that is similar to modern garlic mustard (Alliaria petiolata) and was found inside an Ertebølle culture pot shows that seasonings were already being used (Saul et al. 2013).

Milk acquired a special role in the Neolithic. Traces of it have been found on not only various Neolithic pottery from S or Central Europe, but also in CWC beakers in present-day Finnish territory, where the climatic conditions would seem to be especially unfavourable for agriculture (Cramp et al. 2014). Meanwhile genetic research has shown that the LCT-13910*T allele associated with lactose tolerance is found in the Central European population only from the $1^{\text {st }}$ millennium BC (Witas et al. 2015). Thus, although people could not drink fresh milk, it was considered valuable and was probably consumed fermented.

Isotopic and biomolecular analyses of food residue on pottery have yielded the most information in recent years about nutrition and the food prepared in Lithuanian ceramic vessels. In 2017, a bulk $\delta^{13} \mathrm{C}$ and $\delta^{15} \mathrm{~N}$ stable isotope analysis was conducted on almost 300 samples of encrusted charred food (Piličiauskas et al. 2018), just 11 of which were from SE Lithuania. The one sample from Dubičiai-type (from the Margiai 1 settlement) and the three from Nemunas culture pottery (from the Kabeliai 23, Margiai 1, and Šakès settlements) displayed low $\delta^{15} \mathrm{~N}$ values and a smaller than $10 \mathrm{C}: \mathrm{N}$ ratio characteristic for terrestrial food and very different from aquatic material on so-called Subneolithic pottery from Šventoji, as well as the shores of Lakes Kretuonas and Biržulis. The $\delta^{15} \mathrm{~N}$ values from the Margiai 1 and Kabeliai 23 samples in fact insignificantly exceed the $<6$ boundary characteristic of terrestrial food and are fairly close to some of the samples from Narva culture pottery from the Papiškès (Vilnius District) and Daktariške (on the shore of Lake Biržulis in Telšiai District) settlements (Piličiauskas et al. 2018, p. 24-28, Appendix, no. 132 and nos. 29, 38, 111, 199).
The Margiai 1 settlement existed on the $\mathrm{N}$ shore of large Lake Duba (Fig. 1) during the Neolithic and therefore, based on environmental determinism, at least a slight exploitation of the water resources would have been likely.

The remaining seven samples from SE Lithuania: from the Karaviškès 6 (1 sample), Katros Ištakos 1 (2), and Margiai 1 (4) settlements were of CWC pottery. They did not differ from the general context of the Lithuanian CWC inland settlements and were also fairly close to this region's earlier pottery (Piličiauskas et al. 2018). If a transition from aquatic to terrestrial food can be seen on the coast and in the Narva culture inland settlements, a transition that is connected with the keeping of domesticated animals and the consumption of their milk, then it would seem that the subsistence strategy could have remained unchanged in SE Lithuania right until the Bronze Age.

An organic residue analysis using molecular and isotopic characterization techniques has yielded more detailed information about the animal food that was consumed and the diversity of the food prepared in ceramic vessels. In the investigation, Dubičiai and Sokołówek type, Nemunas culture, and other similar pottery was ascribed in general to the Early Neolithic SE Baltic culture group (Courel et al. 2020). This was actually a correct decision not only for the creation of a statistically reliable sample, but also for the possibility of better perceiving the lifestyle features more characteristic of this region's communities. Of the 667 samples of Baltic region hunter-gatherer pottery examined, only seven were from SE Lithuania (the Dubičiai 3, Glūkas 3, Gribaša 4 (2 samples), Karaviškès 6 (2 samples), and Varènè 10) settlements and 15 from the Narva culture Kretuonas (E Lithuania) and Daktariške (W Lithuania) settlements. If the Narva culture pots held food prepared from fresh water resources mixed with the fats and oils from terrestrial foods, then non-ruminant terrestrial animal food 
predominated in SE Lithuania, like in the entire Early Neolithic SE Baltic culture group. TMTD (4,8,12-trimethyltridecanoic acid), which is associated with food from water products, was not identified in any SE Lithuanian sherds, but this aquatic biomarker may not have survived due to the environment, which is unfavourable for organic material. In respect to the $\delta^{13} \mathrm{C}$ values of the $\mathrm{C}_{16: 0}$ and $\mathrm{C}_{18: 0}$ fatty acids, almost all of the samples fell into the range of porcine fat. Only one vessel, which came from the Gribaša 4 settlement, was distinguished by the higher $\delta^{13} \mathrm{C}$ values that lie in the freshwater resource range. A bowl from the Glūkas 3 settlement displayed abietic acid derivatives, which are commonly associated with Betulus sp. tar or Pinus sp. pitch (Courel et al. 2020, Electronic supplementary material, Dataset 1). Birch bark tar was mostly used for gluing broken pots and waterproofing vessels; pine pitch could have also been used for the same purposes (Mitkidou et al. 2008). The thick-walled vessel from Glūkas 3 is in fact not a usual shape from this region; this bowl could have been made especially for resin production.

It is interesting that the presence of dairy products was identified in 13 Ertebølle culture and 2 Narva culture (from Poland and Belarus) vessels (Courel et al. 2020). These investigation results show a much more diverse hunter-gatherer diet and greater interaction with farmers than had previously been thought.

In SE Lithuania, no milk was found not only in the Early-Middle Neolithic pots, but also in the CWC pottery, which is associated with herders. Dairy fats have been discovered only in W Lithuanian pots. Of the 66 samples from investigated GAC (which is associated with the first farmers), Rzucewo, CWC, and Post-CWC pottery, only eight were from SE Lithuanian settlements (2 CWC beakers from Dubičiai 2, a GAC amphora and pot from Gribaša 4, and 4 CWC beakers from Karaviškès 6) (Heron et al. 2015; Robson et al. 2019). Ruminant animal and aquatic-derived food predominated in W Lithuania, while only ruminant fats were usually identified in SE Lithuanian vessels, but non-ruminant animal organic residue was found on CWC beakers from Dubičiai 2 and Karaviškès 6 (Piličiauskas 2018, p. 140, Table 5). Although aquatic biomarkers are absent in SE Lithuanian pottery, the $\delta^{13} \mathrm{C}_{16: 0}$ and $\delta^{13} \mathrm{C}_{18: 0}$ values of these beakers fall into the range of freshwater resources (Robson et al. 2019, Electronic supplementary material, ESM 1).

Fats of animal origin have been discovered in beakers throughout Lithuania, which sort of shows that archaeologists have erroneously interpreted the purpose of these vessels. Judging from the size of the beakers (0.5-0.8 1 capacity), these vessels, from which one individual ate and drank different foods, were used more diversely.

Such broad scale investigations that encompass the entire Baltic region allow the connections between the food used by communities and the cultural traditions reflected in the decoration of the pottery to be better perceived. The maps presented by the investigators to show the spatial distribution of different fatty acids in vessels showed the use of water resource products increasing from $\mathrm{S}$ to $\mathrm{N}$ in the Baltic region, a significantly increasing use of porcine fat from $\mathrm{N}$ to $\mathrm{S}$, especially in the territory of the Early Neolithic SE Baltic culture group, and a significantly declining use of ruminant fat from SW to NE (Courel et al. 2020, Fig. 4). These directions reflect not only different nutrition, but also a distinctive relationship between the community and the natural environment. In analysing the spatial distribution of Early-Middle Neolithic settlements in the E Baltic region, it is possible to notice that the Narva culture communities, who were distinguished by their use of water resources, could have used the river networks and other bodies of water as natural roads, by which to communicate and spread their ideas. Meanwhile SE Lithuania's Neolithic inhabitants, members of the Nemunas culture, even though they settled beside rivers and lakes, travelled only along the banks of 
the rivers, while the bigger rivers like the Neris, Nemunas, and Vistula became natural obstacles that defined the boundaries of the spread of their cultural influence.

\section{CONCLUSIONS}

1. The emergence of clay vessels in the communities of SE Lithuania in the late $6^{\text {th }}$ millennium $\mathrm{BC}$ reflects the beginning of multiple protracted processes. The traditional concept of the 'Neolithic', which is defined by sudden economic changes, is not very suitable for describing these processes, but the terms, 'ceramic Mesolithic' or 'Subneolithic' do not explain the nature of the lifestyle of this region's communities at all. An 'alternative model of Neolithisation' was selected for SE Lithuania. 'Forest Neolithic' hunter-gatherers selectively adopted certain innovations from the agricultural and nonagricultural communities and adapted them to fit their own needs. The emergence of pottery in the $\mathrm{E}$ Baltic region inspired the transformation of the way of life, nutrition, artistic expression, and identifying symbols of the communities making and using pottery and therefore it can justifiably be associated with the beginning of the Neolithic.

2. The emergence of pottery in SE Lithuania, like in the rest of the Baltic region, is connected not with Central European farmers, but with the influence of non-agrarian communities from the east. The first pottery with organic temper differed little from the traditions of the Narva culture, which existed to the $\mathrm{N}$, but the distinctive Dubičiai type pottery appeared through influence of the Dnieper-Don culture.

3. Pottery with organic temper is very diverse in SE Lithuania: not only the type of organic material and its preparation differ, but also the coiling styles. The earliest pottery is porous and fairly coarse, while the thin-walled cups with a compacted clay body should be associated with the influence of the Late Neolithic Narva culture.
4. From the $4^{\text {th }}$ millennium BC, pottery became a clear representative symbol of various communities. Nemunas culture pottery with its mineral temper and unique spatial decoration should be associated with the work of immigrant male professional potters. They display not only the large fingerprints of the potters, but also vessel decoration methods requiring skilfulness and extraordinary spatial thinking rather than thoroughness.

5. The fragments of pottery of varying coiling and decoration quality that have been discovered in SE Lithuania reflect the learning process. It is likely that in the Stone Age children of roughly 12 years of age began to make pots, but adults could also copy skilfully made vessels or improve their skills. The attitude towards the aesthetic qualities of vessels differed greatly between the communities.

6. Pottery ascribable to the CWC is scarce and very diverse in SE Lithuania; therefore it is unlikely that massive migration occurred in this region. It would seem, compared to the decoration of the Middle Neolithic vessels, that pottery lost its representative function for communities during the CWC period. It was more associated with the home environment; this is reflected by the grog, which is characteristic of CWC vessels and can be associated with the fire site area. The size of the nail and finger prints often discovered on CWC pots allow one to state that pottery making had become a woman's job.

7. Both the investigation of the food residue discovered on pots and the spatial distribution of the settlements show that Narva culture communities not only exploited water resources, but could have also travelled on rivers or other bodies of water, but for the Nemunas culture people, who were inclined to eat terrestrial food, the larger rivers became natural obstacles that defined the boundaries of the spread of their influence.

8. A diversity of influences by different communities is reflected in SE Lithuanian Neolithic pottery. The elements of various traditions that 
blended in the coiling and decoration of vessels allows one to speak about peaceful consistent interaction between hunter-gatherers and agrarian societies.

\section{Acknowledgements}

I would like to thank the Lithuanian Council for Culture for its grant, which allowed me to experiment, educate, and observe human behaviour and motivation in producing pottery as well as to take a new look at the SE Lithuanian Stone Age sherds and to systemise them in a new database. I would especially like to thank Dalia Ostrauskienè, Saulius Žegunis, and Gediminas Petrauskas, archaeologists at the National Museum of Lithuania, for the opportunity they gave me to become acquainted with all of the Neolithic pottery and to study it. And I would like to thank Dainius Strazdas, Jurgita Radžiūnaite, and Virginija Rimkutè for their advice.

Translated by Jeffrey Arthur BAKANAUSKAS

\section{REFERENCES}

Akulov, A., 2019. A Preliminary Attempt to Reconstruct some Tools and Techniques of Ornamentation of the Comb-Pit Ware from the Site of Hepojarvi (Karelian Isthmus, Leningrad Oblast, Russia). EXARC Journal Issue, 2. [online] Available at: <https://exarc.net/ark:/88735/10421> [Accessed 18 August 2020].

Antanaitis-Jacobs, I., Girininkas, A., 2002. Periodization and chronology of the Neolithic in Lithuania. Archaeologia Baltica, 5, 9-39.

Baltrūnas, V., Barzdžiuvienė, V., Blažauskas, N., et al., 2001. Akmens amžius Pietų Lietuvoje. Vilnius: Geologijos institutas.

Binford, L. R., 1983. In Pursuit of the Past. Decoding tje Archaeological Record. London: Thames and Hudson.
Blaževičius, P., 2019. Child labour based on dermatoglyphic research of ceramic objects. Childhood in the Past, 12(1), 6-17

Bobrinsky, A. A., Vasilyeva, I. N., 2012. Plastic raw materials in Neolithic pottery production. Documenta Praehistorica, 39, 67-74.

Brazaitis D., 2005. Neolitizacijos proceso pradžia Lietuvoje. $L A, 29,241-252$.

Czarniavskij, M. M., 2001. Nieolit z griebienczata-nakolczatai i nakolczatai kieramikai Zachadniaj Białorusi. Asablivasci evaliucyi. In: Czebreszuk, J., Kryvalcevicz, M., Makarewicz, P., eds. Od neolityzacji do początków epoki brązu. Przemiany kulturowe $w$ międzyrzeczu Odry i Dniepru między VI $i$ II tys. przed Chr. Poznań: Wyd. Poznańskie, 231-240.

Childe, G., 1936. Man Makes Himself. London: Watts.

Courel, B., Robson, H. K., Lucquin, A., Dolbunova, E., Oras, E. et al., 2020. Organic residue analysis shows sub-regional patterns in the use of pottery by Northern European hunter-gatherers. Royal Society Open Science, 7 (4). https://doi.org/10.1098/rsos.192016.

Cramp, L. J. E., Evershed, R. P., Levanto M., et al. 2014. Neolithic dairy farming at the extreme of agriculture in northern Europe. Proceedings of the Royal Society. B, 281 (1791). https://doi.org/10.1098/ rspb.2014.0819.

Dolbunova, E. V., Tsybryi, V. V., Mazurkevich, A. N. et al., 2020. Subsistence strategies and the origin of early Neolithic community in the lower Don River valley (Rakushechny Yar site, early/middle 6th millennium cal BC): First results. Quaternary International, 541, 115-129.

Dumpe, B., Stivrins, N., 2015. Organic inclusions in Middle and Late Iron Age $\left(5^{\text {th }}-12^{\text {th }}\right.$ century) hand-built pottery in present-day Latvia. Journal of Archaeological Science, 57, 239-247.

Furholt, M., 2018. Massive Migrations? The Impact of Recent aDNA Studies on our View of Third Millennium Europe. European Journal of Archaeology, 21 (2), 159-191. 
Grömer, K., Kern, D., 2010. Technical data and experiments on corded ware. Journal of Archaeological Science, 37, 3136-3145.

Haak, W., Lazaridis, I., Patterson, N. et al. 2015. Massive migration from the steppe was a source for Indo-European languages in Europe. Nature, 522, 207-211.

Heron, C., Craig, O. E., Luquin, A., Steele, V. J., Thompson, A., Piličiauskas, G. 2015. Cooking fish and drinking milk? Patterns in pottery use in the southeastern Baltic, 3300-2400 cal BC. Journal of Archaeological Science, 63, 33-43.

Hodder, I., 1990. The Domestication of Europe. Oxford: Blackwell.

Holmqvist, E., Larsson, Å., Kriiska, A., Palonen, V., Pesonen, P., Mizohata, K., Kouki, P., Räisänen, J., 2018. Tracing grog and pots to reveal neolithic Corded Ware Culture contacts in the Baltic Sea region (SEM-EDS, PIXE). Journal of Archaeological Science, 91, 77-91.

Hommel, P., 2018. What's the Point?: Globalization and the Emergence of Ceramic-using Hunter-gatherers in Northern Eurasia. In: Boivin, N., Frachetti, M., eds. Globalization in Prehistory: Contact, Exchange, and the 'People Without History. Cambridge: Cambridge University Press, 15-42.

Iršènas, M., Butrimas, A., 2000. Daktariškès 5-osios gyvenvietès keramikos su organinès kilmès priemaišomis ornamentika. $L A, 19,125-138$.

Jordan, P., Zvelebil, M., 2009. Ex oriente lux: the prehistory of hunter-gatherer ceramic dispersals. In: Jordan, P., Zvelebil, M., eds. Ceramics before farming: the dispersal of pottery among prehistoric Eurasian hunter-gatherers. Walnut Creek: Left Coast, 33-89.

Jordan, P., Gibbs, K., Hommel, P., Piezonka, H., Silva, F., Steele, J., 2016. Modelling the diffusion of pottery technologies across Afro-Eurasia. Antiquity, 90 (351), 590-603.

Józwiak, B., 2003. Społeczności subneolitu wschodnioeuropejskiego na Niżu Polskim w międzyrzeczu Odry i Wisły. Poznań: Uniwersytet Adama Mickiewicza.

Kossina, G., 1911. Die Herkunft der Germanen: zur Methode der Siedlungsarchäologie. Würzburg: Curt Kabitzsch.

Králík, M., Novotný, V., 2003. Epidermal Ridge Breadth: An Indicator of Age and Sex in Paleodermatoglyphics. Variability and Evolution, 11, 5-30.

Kreiter, A., Kalicz, N., Kovács, K., Siklósi, Z., Viktorik, O., 2017. Entangled traditions: Lengyel and Tisza ceramic technology in a Late Neolithic settlement in northern Hungary. Journal of Archaeological Science: Reports, 16, 589-603.

Kriiska, A., 1996. The Neolithic pottery manufacturing technique of the lower course of the Narva River. In: Hackens, T., Hicks, S., Lang, V., eds. Coastal Estonia: Recent Advances in Environmental and Cultural History. Strassbourg: Rixensart, 373-384.

Kriiska, A. Oras, E., Lõugas, L., Meadows, J., Craig, O., Lucquin, A., 2017. Late Mesolithic Narva Stage in Estonia: Pottery, Settlement Types and Chronology. Estonian Journal of Archaeology, 21(1), 52-86.

Kristiansen, K., Allentoft, M. E., Frei, K. M., Iversen, R., Johannsen, N. N., Kroonen, G., et al. 2017. Re-theorising Mobility and the Formation of Culture and Language Among the Corded Ware Culture in Europe. Antiquity, 91, 334-347.

Kukawka, S., 2015. Początki Kultury pucharów lejkowatych na niżu Polskim. Folia Praehistorica Posnaniensia, 20, 277-300.

Kulkova, M., Kulkov, A., 2016. The Identification of Organic Temper in Neolithic Pottery from Russia and Belarus. The Old Potter's Almanack, 21 (1), 2-12.

Larsson, Å M., 2009. Breaking and Making Bodies and Pots. Material and Ritual Practices in Sweden in the Third Millennium BC. (=Aun, 40). Uppsala: Uppsala Universitet.

Linderholm, A., Kılınç, G. M., Szczepanek, A. et al., 2020. Corded Ware cultural complexity 
uncovered using genomic and isotopic analysis from south-eastern Poland. Science Reports, 10, 6885.

Lubbock, J., 1865. Pre-historic Times, as illustrated by Ancient Remains, and the Manners and Customs of Modern Savages. London and Edinburgh: Williams and Norgate.

Marcinkevičiūtè, E., 2016. A New Perspective on Neolithic sites in the Dubičiai Microregion Using a GIS spatial analysis. Archaeologia Lituana, 17, 57-76.

Mikšaitè, S., 2005. Production of Ceramics of Narva Culture (Reconstructions based on Experimental Archaeology). Estonian Journal of Archaeology, 9(1), 60-72.

Mitkidou, S., Dimitrakoudi, E., Urem-Kotsou, et al., 2008. Organic residue analysis of Neolithic pottery from North Greece. Microchimica Acta, 160, 493-498.

Moskal-del Hoyo, M., Rauba-Bukowska, A., Lityńska-Zając, M., Mueller-Bieniek, A., CzekajZastawny, A., 2017. Plant materials used as temper in the oldest Neolithic pottery from south-eastern Poland. Vegetation History and Archaeobotany, 26, 329-344.

Motuzaite Matuzeviciute, G., 2018. The Possible Geographic Margin Effect on the Delay of Agriculture Introduction into the East Baltic. Estonian Journal of Archaeology, 22 (2), 149-162.

Nowak, M., 2009. Drugi etap neolityzacji ziem polskich. Kraków: Księgarnia Akademicka Uniwersytetu Jagiellońskiego.

Piezonka, H., 2015. Jäger, Fischer, Töpfer. Wildbeutergruppen mit früher Keramik in Nordosteuropa im 6. und 5. Jahrtausend v. Chr. (=Archäologie in Eurasien, 30). Bonn: Habelt-Verlag.

Piličiauskas, G., 2016. Lietuvos pajūris subneolite ir neolite. Žemès ūkio pradžia. $L A, 42,25-103$.

Piličiauskas, G., 2018. Virvelinès keramikos kultūra Lietuvoje 2800-2400 BC. Vilnius: Lietuvos istorijos institutas.

Piličiauskas, G., Skipitytė, R., Heron, C., 2018. Mityba Lietuvoje 4500-1500 cal BC maisto liekanų keramikoje bendrųjų mėginių izotopinių tyrimų duomenimis. $L A, 44,9-41$.

Podènas, V., Luchtanas, A., Čivilytè, A., 2016. Narkūnų piliakalnių ir papèdès gyvenvietès keramika: elgsenos atspindžiai. $L A, 42,191-241$.

Rimantienè, R., 1984. Akmens amžius Lietuvoje. Vilnius: Mokslas.

Rimantienė R., 1992. Šakès - neolito gyvenvietè. $L A, 8,16-34$.

Rimantienè, R., 1999a. Margių 1-oji gyvenvietè. $L A, 16,109-170$.

Rimantienè, R., 1999b. Barzdžio miško gyvenvietè. $L A, 16,171-208$.

Robson, H. K., Skipitytè, R., Piličiauskienè, G., et al., 2019. Diet, cuisine and consumption practices of the first farmers in the southeastern Baltic. Archaeological and Anthropological Science, 11, 4011-4024.

Sanders, A., 2015. Fingerprints, sex, state, and the organization of the Tell Leilan ceramic industry. Journal of Archaeological Science, 57, 223-238.

Saul, H., Madella, M., Fischer, A., Glykou, A., Hartz, S., et al., 2013. Phytoliths in Pottery Reveal the Use of Spice in European Prehistoric Cuisine. PLoS ONE. https://doi.org/10.1371/journal.pone.0070583.

Šatavičius, E. 2006. Žvalgymai ir žvalgomieji tyrimai Rytų ir Pietų Lietuvoje. Archeologiniai tyrinejimai Lietuvoje 2004 metais, 291-305.

Taraškevičius, R., Bliujienè, A., Karmaza, B., et al., 2013. Geocheminiai tyrimų metodai archeologijoje. In: Merkevičius, A., ed. Metodai Lietuvos archeologijoje. Mokslas ir technologijos praeičiai pažinti. Vilnius: Vilniaus universitetas, 249-304.

Tkachou, A., 2018. Early Neolithic Pottery from Western Belarus. Archaeologia Baltica, 25, 82-99.

Tsetlin, Yu. B., 2018. The origin of ancient pottery production. Journal of Historical Archaeology \& Anthropological Sciences, 3 (2), 209-214.

Troskosky, Ch. B., White, J. M., Gaižauskas, L., 2019. A Unified Model for the Governing Dynamics of Agricultural Frontier Zones. LA, 45, 145-167. 
Witas, H. W., Płoszaj, T., Jędrychowska-Dańska, K., et al., 2015. Hunting for the LCT-13910^T Allele between the Middle Neolithic and the Middle Ages Suggests Its Absence in Dairying LBK People Entering the Kuyavia Region in the 8th Millennium BP. PLoS ONE. https://doi.org/10.1371/journal.pone.0122384.

Zvelebil, M., 2001. The agricultural transition and the origins of Neolithic society in Europe. Documenta Praehistorica, 28, 1-27.

Çilingiroğlu, Ç., 2005. The concept of „Neolithic package": considering its meaning and applicability. Documenta Praehistorica, 32, 1-13.

Грикпедис, М., Эндо, Э., Мотузайте Матузевичюте, Г., Кривальцевич, Н., Ткачева, M., 2018. SEMисследование отпечатков растений на неолитической керамике бассейна реки Припять. In: Лозовская, О. В., Выборнов, А. А., Долбунова, Е. В., eds. Стратегии жизнеобеспечения в каменном веке, прямые и косвенные свидетельства рыболовства и собирательства. Материаль международной конферениии, посвященной 50-летию B. М. Лозовского. Санкт-Петербург: ИИМК РАН, 210-213.

Марцинкевичюте, Э., 2010. Нарвская культура в Южной Литве. Матэрыялы па археалогіі Белаpyci, 18, 147-160.

Нордквист, К., Крийска, А., 2018. Неолит Северо-Востока Европы в балтийской перспективе. Российская археология, 2, 162 -174.

\section{ABBREVIATIONS}

CWC - Corded Ware culture

GAC - Globular Amphora culture

TRB - Funnel Beaker culture

LA - Lietuvos archeologija

\title{
NEOLITO BENDRUOMENĖS IR JŲ KERAMIKA PIETRYČIŲ LIETUVOJE
}

\author{
Eglè Šatavičè
}

\section{Santrauka}

Pietryčių Lietuva - vienas anksčiausiai pradètų tyrinèti Lietuvos regionų. Dar XIX-XX a. sandūroje smèlinguose paupiuose ir paežeriuose pradèta rinkti titnaginiai radiniai ir ịvairiais įspaudais puoštų molinių indų šukès. Paviršiuje išpustyti titnaginiai dirbiniai leidžia lengvai aptikti akmens amžiaus gyvenvietes, tačiau dèl smèlingo grunto itin prastai išlieka organiniai radiniai, o titnago inventorius ir smulkios keramikos šukès yra stratigrafiškai susimaišę. Dažnai atrodo, kad tokių Pietryčių Lietuvos gyvenviečių tyrimai nelabai prasmingi, tačiau ši medžiaga itin svarbi mėginant suprasti viso Rytų Baltijos regiono neolito bendruomenių tradicijas, demografinę struktūrą nulèmusias migracijas bei ịvairiomis kryptimis plitusias kultūrines įtakas.
Molinių indų atsiradimas Pietryčių Lietuvos bendruomenėse VI tūkstantm. pr. Kr. pabaigoje atspindi ilgai trukusių daugialypių procesų pradžią. Jiems apibūdinti nelabai tinka tradicinè neolito sąvoka, siejama su staigiais ekonominiais pokyčiais. Lietuvoje ryškesnių žemdirbystės požymių atsirado tik I tūkstantm. pr. Kr., todèl, mėginant statiškai taikyti Vakarų ir Vidurio Europai būdingus neolito kriterijus, Rytų Baltijos regione šis laikotarpis išvis negali būti išskiriamas.

Buvusioje Sovietų Sąjungoje, taip pat Lietuvoje laikytasi nuo XX a. pradžios paveldèto kultūrinioistorinio modelio neolito pradžią siejant su materialiosios kultūros pokyčiais - keramikos atsiradimu. Pastaraisiais metais, atkreipiant dėmesị i Rytų 
Europos neolitinès medžiagos nereprezentatyvumą, siūlomi subneolito ar keraminio mezolito terminai, tačiau jie nepaaiškina šio regiono bendruomeniu gyvensenos savitumo. Neolito pradžią mėginama sieti su DNR tyrimais patvirtinta masine Virvelinès keramikos kultūros (toliau - VKK) atstovų migracija, kuri ị Baltijos regioną tariamai atnešè indoeuropiečių kalbą ir gyvulininkystę.

Tokia statiška kalbos, kultūros ir gyvenimo būdo sąsaja su genetika negali kokybiškai paaiškinti daugialypių socialinių ir kultūrinių procesų. Neolitizacija neturétų būti siejama vien su naminių augalų ir gyvūnų atsiradimu ar imigrantų antplūdžiu: pokyčiai negali plisti vien prievarta - svarbus ir atgalinis ryšys. Senoji medžiotojų ir maisto rankiotojų visuomenè turejo būti pribrendusi ir motyvuota priimti naujoves. Skirtinga geografinè padètis, žmonių santykis su gamtine aplinka, gebėjimas daryti ittaką kitoms bendruomenèms ar priimti jų itaką, gyvenimo būdo, mąstymo, ịpročių ir ịvairių igūdžiu skirtumai nulèmè neolitizacijos įvairovę. VI-II tūkstantm. pr. Kr. Pietryčiu Lietuvoje vykusiems procesams apibūdinti labiausiai tinka mišku neolito terminas, pabrěžiantis savitą medžiotojų-rankiotojų bendruomenių pasirinkimą priimti tik kai kuriuos gamybinio ūkio elementus nekeičiant gamtinès aplinkos bei išlaikant pusiausvyrą.

Akmens amžiaus indų šukès Pietryčių Lietuvoje yra svarbiausias informacijos šaltinis mėginant suvokti šio regiono bendruomenių gyvenimo būdą, mitybą, tarpusavio ryšius, ịvairių ịtakų sąveiką kuriant tradicijas. Keramikos atsiradimas sietinas ne su Vidurio Europos žemdirbiais, bet su neagrarinių bendruomenių ịtaka iš Rytų. Molinių indų lipdymo ir ornamentavimo tradicijos, kaip ir kitos naujovès, galejo plačiai paplisti senaisiais, dar paleolite atsiradusiais bendravimo tinklais. Tradicijos vystėsi ir keitėi, ne tik veikiamos bendruomenių tarpusavio ịtakos, bet ir dèl individualių puodžių saviraiškos suteikiant indams naujų estetinių ar praktinių savybių.
Absoliuti dauguma Pietryčiu Lietuvos akmens amžiaus keramikos aptikta Varénos r. sav., paskutinio apledejjimo Dainavos fliuvioglacialinių žemumų srityje, ị P nuo Merkio arba netoli jo. Plačiausiai tyrinètas Dubičių mikroregionas, kuriame žymiausios Barzdžio miško, Dubičiu 1-3, Gribašos 4, Karaviškių 6, Katros 1-4, Katros ištakų, Lynupio, Margių, Šakių gyvenvietės buvo išsidèsčiusios didelių neolite egzistavusių ežerų pakrantėse. Taip pat plačiau tyrinètos Grūdos ežero (Kabelių 23) bei Glūko ir Varènio ežerų (Glūko 3, Varẻnės 10 gyvenvietės) apylinkès (1 pav.).

Ankstyviausia keramika su organinèmis priemaišomis molio masëje menkai skyrèsi nuo šiauriau gyvavusios Narvos kultūros (3 pav.) keramikos. Indai galëjo būti lipdomi iš ežerų ar upių pakrantèse randamo dumblingo molio ar šlyno su natūraliai jame susiklosčiusia organika. Panaši molio masè išliko ir pradejjus naudoti mineralines priemaišas. Be grūsto granito trupinių, dažnai matyti ir išdegusios organikos porų (2 pav.).

Dèl Dniepro-Dono kultūros ịtakos atsirado savita Dubičių tipo keramika, kuriai būdingi giliomis duobutèmis aplink pakraštèli ornamentuoti smailiadugniai puodai ir molio masè su ilgais miglinių žolių lapais (4 pav.). Ankstyvoji keramika su augalinèmis priemaišomis porèta, gana negrabi, tačiau aptinkama ir plonasienių tankintos molio masès puodelių fragmentų, sietinų su vèlyvojo neolito Narvos kultūros ịtaka (5 pav.). Augalų fragmentų pasitaiko ne tik šios keramikos molio masèje, bet ir išorès ornamentikoje. Vienas iš šių indų puoštas paprastosios gervuogès gabalèliais ir sèklomis (9 pav.).

Indas buvo lipdomas iš volelių arba juostelių nuo dugno ị viršu. Jungimo vietos užlygintos vidinị ir išorinị apatinio volelio paviršių tempiant aukštyn (U tipo jungtis), platinant indo angą - vidinis paviršius temptas aukštyn, o išorinis - žemyn ( $\mathrm{N}$ tipo jungtis) (7: 2 pav.), siaurinant angą - išorinis paviršius temptas aukštyn, o vidinis - žemyn (Z tipo jungtis) (7: 1 pav.). Pabaigoje, kad tvirčiau voleliai sukibtų, 
vidinis ir išorinis indo paviršius ịstrižai buvo užtrintas žolių gniūžte ar šukų formos įrankiu.

Pietryčių Lietuvoje aptinkami nevienodos lipdymo ir dekoravimo kokybès keramikos fragmentai atskleidžia mokymosi procesą. Ryškiausiai tai iliustruoja šukè su prastai užlyginta volelių jungimo vieta (7: 2 pav.), taip pat netoliese aptikta kita, galbūt to paties indo šukè su 12,3 metų vaiko piršto ispaudu. Turbūt mokèsi lipdyti ne tik vaikai, bet ir suaugusieji.

Viduriniame neolite, IV tūkstantm. pr. Kr., keramika tapo ryškiu reprezentaciniu įvairių bendruomenių simboliu. Pietryčių Lietuvoje aptinkama unikalia erdvine ornamentika (11, 12 pav.) bei meistriškumu išsiskiriančių Nemuno kultūros puodų fragmentų. Ant šios keramikos išlikę lipdytojų stambių pirštų atspaudai (8 pav.) paneigia teoriją, kad indus lipdydavo tik moterys, bei rodo naują pažangesnị keramikos raidos etapą, susijusi su keliaujančių puodžių specializacija. Tikètina, dèl igūdžių puodžiai turèjo ypatingą statusą visuomenèje, vietiniai mėgino juos kopijuoti, mokèsi naujų lipdymo ir ornamentavimo tradicijų, todèl, bendruomenèje esant vos vienam ar keliems ateiviams, galëjo ženkliai kisti materialioji kultūra, ir be prievartos ar didelès migracijos bangos ịsivyrauti vyriškąja linija perduodama nauja genetinè informacija.

Vèlyvojo neolito VKK priskiriama keramika Pietryčių Lietuvoje negausi ir labai ịvairi. Itvairaus storio, tankumo, dažniausiai S krypties pynimo virvučių, suvytų iš žolès ar liepos karnos, ịspaudai (10 pav.) būdingi ne tik VKK, bet ir kitoms kultūrinèms tradicijoms. VKK būdingas šamotas, t. y. senų indų trupiniai, molio masèje sunkiai gali būti atpažįstami nusizulinusiuose šukių lūžiuose, o pjūviuose matyti smèlio, taip pat molingų, anglingų ar geležingų dalelių priemaišos (6 pav.). Su VKK siejamas keramikos išdegimas kontroliuojamoje redukcinejje aplinkoje nustatytas vos keliems indams (6: 1; 13 pav.).

Lyginant su vidurinio neolito indų ornamentika, atrodo, kad vèlyvajame neolite keramika prarado reprezentacinę bendruomenių funkciją. Ši keramika labiau sietina su namų aplinka: ant indų dažnai aptinkamų nagų ir pirštų ịspaudų dydis leidžia teigti lipdymas tapo moterų užsièmimu. VKK keramikos lipdymo tradicijas geriausiai atspindi Iano Hodderio (1990, p. 65) pastebèta žemdirbių visuomenei būdinga moters, namų, židinio aplinkos ir keramikos sąsaja. Atrodo, moterys, lipdydamos indus šalia židinio, molio masei liesinti iš laužavietès pasisemdavo smèlio su argilito, geležingų mineralų, suodžių dalelėmis ir sudužusių indų trupiniais.

Moliniuose akmens amžiaus induose maistas buvo ne tik laikomas, bet ir gaminamas, verdamas, tačiau dèl destrukcinio smèlinès aplinkos poveikio šukių su prikepusio maisto liekanomis Pietryčių Lietuvoje aptinkama itin retai. Keramikoje išlikusių lipidų stabiliųjų izotopų bei biomolekuliniai tyrimai suteikè daug informacijos apie žmonių mitybą. Per visą neolito laikotarpi Pietryčių Lietuvoje vyravo sausumos maisto vartojimas: pradžioje daugiau valgyta neatrajojančių (kiaulienos) gyvulinès kilmès riebalų, o neolitui baigiantis pagausèjo atrajojančių (galbūt galvijų) gyvūnų riebalų suvartojimas, tačiau pieno pèdsakų induose neaptikta.

Tiek puoduose aptiktų maisto likučių tyrimai, tiek erdvinis gyvenviečių išsidèstymas rodo, kad vandens išteklių naudojimu išsiskiriančioms Narvos kultūros bendruomenèms upių tinklai ir kiti vandens telkiniai buvo kaip gamtiniai keliai, kuriais jie bendravo ir platino savo idejjas. Nors Pietryčių Lietuvos neolito gyventojai įsikurdavo prie upių ir ežerų, tačiau keliavo paupiais, o didesnès upès tapdavo natūraliomis kliūtimis bei jų kultūrinès ịtakos plitimo ribomis.

Neolitinejje Pietryčių Lietuvos keramikoje atsiskleidžia tiek medžiotojų-rankiotojų, tiek žvejų bei gyvulių augintojų bendruomenių tarpusavio ịtakų ivairovè. Indų lipdymo ir puošybos tradicijose derinti skirtingų kultūrų elementai leidžia spèti, kad buvo taikiai ir nuosekliai bendradarbiaujama. 


\section{ILIUSTRACIJŲ SĄRAŠAS}

1 pav. PR Lietuvos neolitinių gyvenviečiu (pažymètos raudonai) žemèlapis. Straipsnyje minimos gyvenvietės: Dubičių mikroregionas (1 - Barzdžio miškas 1; 2 - Dubičiai 1; 3 - Dubičiai 2; 4 - Dubičiai 3; 5 - Dubičiai-Draciliške; 6 - Gribaša 4; 7 - Karaviškès 6; 8 Katra 1; 9 - Katra 4; 10 - Katros ištakos; 11 - Lynupis; 12 - Margiai 1; 13 - Šakès); Grūdos ež. mikroregionas (14 - Kabeliai 23); Glūko-Varènio ež. mikroregionas (15 - Glūkas 3; 16 - Varènè 10). E. Šatavičés brèz.

2 pav. Šukių su mineralinèmis priemaišomis pjūviuose matomas molio masès susisluoksniavimas ir ìvairaus dydžio organikos pedsakai: 1,4- Margiai 1;2, 3 - Barzdžio miškas 1. E. Šatavičés nuotr.

3 pav. Dubičių-Draciliškès gyvenvietės šukè su grūstų kriauklių priemaišomis ir jos pjūvis. S. Širvydaitès-Šliūpienès nuotr.

4 pav. Dubičių tipo šukès (Šakių gyvenvietè) lūžyje matomi ilgi lapai. E. Šatavičès nuotr.

5 pav. Šukių iš Barzdžio miško gyvenvietè pjūviuose matomi žolès varpos fragmentai: $1 \mathrm{~A}, 2 \mathrm{~A}$ - stereomikroskopu; 1B, 2B - SEM). E. Šatavičès nuotr., SEM - R. Vargalio nuotr. (Vilniaus universiteto Chemijos institutas)
6 pav. Šukių iš Margių 1 gyvenvietès pjūviuose matoma šamoto priemaišų ịvairovè. E. Šatavičès nuotr.

7 pav. Voleliu jungimo pavyzdžiai: $1-\mathrm{Z}$ ir U tipo jungtys matomos šukès pjūvyje (Margiụ 1 gyvenvietè); 2 - prastai užlyginta $\mathrm{N}$ tipo jungtis šukeje iš Katros 1 gyvenvietès. E. Šatavičés nuotr.

8 pav. Suaugusio vyro piršto atspaudas ant Nemuno kultūros puodo pakraštelio iš Šakių gyvenvietès. E. Šatavičés nuotr.

9 pav. Paprastosios gervuogès sẻklas primenantys i̇spaudai ant šukès paviršiaus iš Barzdžio miško gyvenvietès ir Rubus caesius L. sèklos. Iš <http:// climbers.lsa.umich.edu/?p=1063> [Žiūrèta $2020 \mathrm{~m}$. gegužès 5 d.] ir E. Šatavičès nuotr.

10 pav. Virvučių i̇spaudai ant šukių paviršiaus: 1, 2 - Margių 1; 3 - Šakès. E. Šatavičés nuotr.

11 pav. Terasinių juostelių ornamentai: 1-7 - Margiai 1; 8 - Karaviškių 6; 9-11 - Šakès. E. Šatavičès nuotr.

12 pav. Nemuno kultūros puodo pakraštelis iš Kabelių 23 gyvenvietès. E. Šatavičés nuotr.

13 pav. Redukcinèje aplinkoje išdegtų indų šukès iš Šakių gyvenvietès. E. Šatavičés nuotr. 